Article

\title{
Squeezed from All Sides: Urbanization, Invasive Species, and Climate Change Threaten Riparian Forest Buffers
}

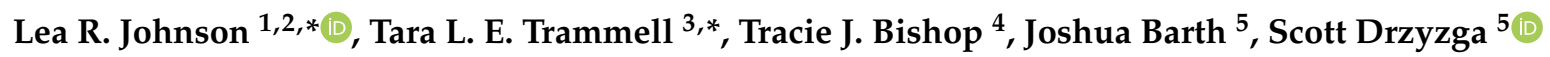 \\ and Claire Jantz ${ }^{5}$ \\ 1 Research and Conservation Division, Longwood Gardens, Kennett Square, PA 19348, USA \\ 2 Department of Plant Science \& Landscape Architecture, University of Maryland, \\ College Park, MD 20742, USA \\ 3 Department of Plant and Soil Sciences, University of Delaware, Newark, DE 19716, USA \\ 4 Department of Agriculture, Food and Resource Sciences, GeoTech Lab, University of Maryland Eastern \\ Shore, Princess Anne, MD 21853, USA; tjbishop@umes.edu \\ 5 Department of Geography-Earth Science, Center for Land Use and Sustainability, Shippensburg University, \\ Shippensburg, PA 17257, USA; jb7337@ship.edu (J.B.); sadrzy@ship.edu (S.D.); cajant@ship.edu (C.J.) \\ * Correspondence: ljohnson@longwoodgardens.org (L.R.J.); ttram@udel.edu (T.L.E.T.); \\ Tel.: +1-(610)-388-5349 (L.R.J.); +1-(302)-831-1387 (T.L.E.T.)
}

Received: 31 December 2019; Accepted: 13 February 2020; Published: 15 February 2020

\begin{abstract}
Streamside forests of urbanizing coastal regions lie at the nexus of global changes: rising sea levels, increasing storm surge, expanding urban development, and invasive species. To understand how these combined stressors affect forest conditions, we identified forest patches adjacent to urban land, analyzed adjacent land cover, modeled forest inundation, and sampled 100 sites across the Chesapeake Bay and Delaware Bay watersheds. We found that the majority of forest patches are adjacent to urban land and projected flooding will affect 8-19\% of regional forested land. We observed non-native invasive plants in $94 \%$ of forest plots. Trees were predominantly native, but over half of shrub stems were invasive species and more than $80 \%$ of plots contained invasive woody vines. Disturbance of human origin was correlated with abundance of invasive trees. Signs of deer activity were common. Richness and number of growth forms of invasive plants were related to adjacent agricultural land cover. These data reveal that streamside forests are impacted by the interacting stressors of urbanization, climate change, and invasive species spread. Our results emphasize the importance of protection and restoration of forests in urban regions and point to the need for a social-ecological systems approach to improve their condition.
\end{abstract}

Keywords: forest patch; storm surge; sea level rise; urban ecology; plant community; disturbance; social-ecological system; invasive species; climate change; spatial analysis

\section{Introduction}

Forests in urbanizing coastal zones are undergoing unprecedented change as urbanization accelerates simultaneously with invasive species spread and climate change. Coastal ecosystems are vulnerable to global climate change as sea levels rise and storm surge events increase [1-4]. They are also at risk for increased urbanization and development pressures because many urban centers occur in coastal areas. Seventy-five percent of the world's largest cities-and 65\% of the densest cities-are located in coastal zones [5], and population growth is projected to increase in coastal cities [6]. At the same time, cities are hotspots for introduction of non-native species [7]. Streamside forests of urbanizing coastal regions lie at the nexus of these global changes, yet the extent and potential impact of these 
combined stressors on riparian urban forests and on their ability to provide valuable water filtration and support for biodiversity is currently unknown. These forests are "squeezed" from all sides by adjacent urbanization on land, rising sea levels and storm surge, and from within by non-native invasive plants (Figure 1). Understanding relationships between urban riparian forests and the combined effects of urbanization, climate change, and invasive species requires a social-ecological approach.

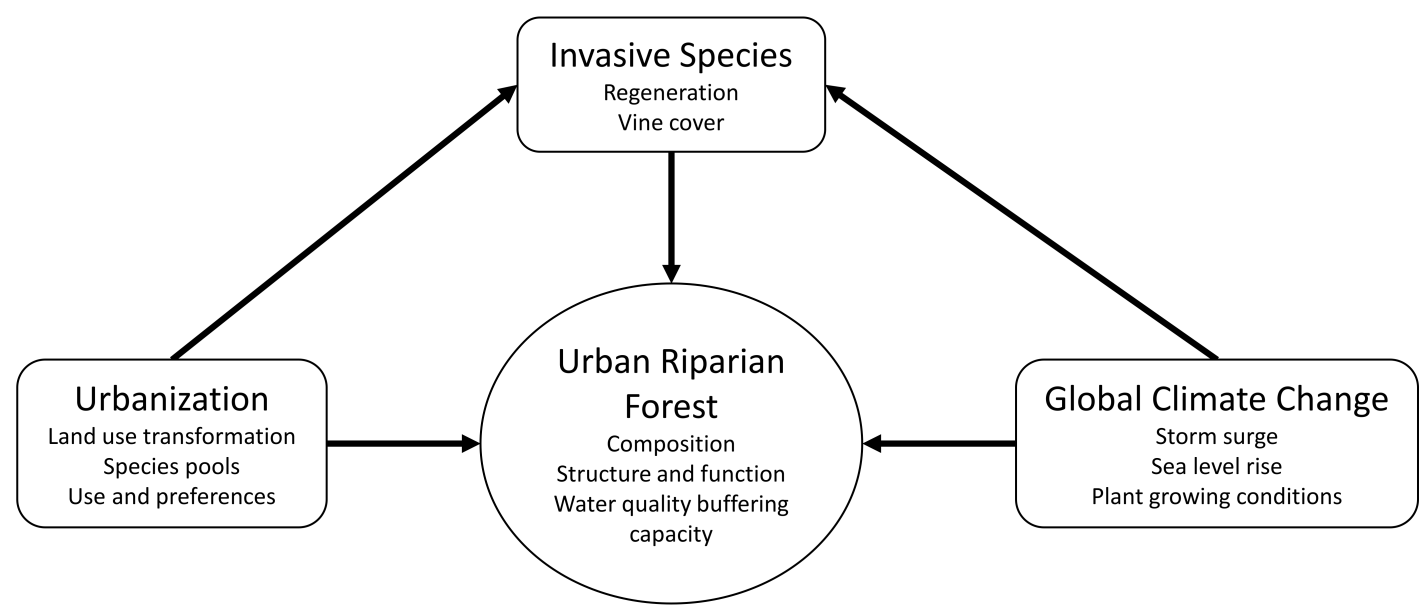

Figure 1. Conceptual model depicting urbanization, global climate change, and invasive species impacts on urban forest buffers along stream corridors. We propose that urban riparian buffers will experience shifts in species composition and subsequent ecological functions due to combined effects of sea level rise, urbanization, and invasive species, and, thus, are "squeezed from all sides". Anthropogenic factors are the ultimate driver of ecosystem change.

The structure, composition, and ecosystem functions of forest patches are affected by landscape-scale fragmentation, isolation, and adjacent land use change due to urban land use transformation [8,9], and also by parcel-scale human activities [10,11]. Management actions affecting these forests range from biodiversity conservation to lumber production, and also include actions based on social perceptions and motivations. Land owners or neighbors may choose to thin or cut forests to remove "messy" vegetation [12,13] or improve views of waterways. Riparian vegetation is constricted in urban areas by hardened shorelines, and by housing development situated as near as possible to valued water views. Proximity of the built environment to the water can prevent migration of buffering vegetation inland with sea level rise, leading to loss of needed nutrient capture capacity for urban and suburban runoff, as well as decreased habitat value. Reduction of riparian vegetation and connectivity between streams and floodplains can further exacerbate urbanization impacts on streams by reducing nutrient retention and flood water retention [14-16]. Both urban conditions and rising saline waters $[17,18]$ affect species composition, which is an underlying determinant of forest health and function.

Predicted global sea level rise and storm surges will increase salinity in coastal urban surface waters, altering adjacent forest function and health. The effects of sea level rise may be compounded further by increased storm surges, salt water intrusion into groundwater and changes in sediment flow [19]. Sea level rise is a global trend with effects that vary widely on a regional level [20], and all levels of government are now developing strategies for climate change adaptation. Vegetation along urban and suburban shorelines is increasingly considered to be important for protective function in relation to storm surge, leading coastal cities to increase buffer vegetation for this purpose [21].

While horizontal stressors from urbanization and sea level rise impact these forests, urban biophysical conditions act as a filter on regional species pools [22] as non-native species are continually introduced into cities $[23,24]$. Top-down impacts on forest regeneration $[25,26]$ and bottom-up alterations to soil processes [27-29] due to invasive plants make urban riparian forests especially vulnerable. Cities are centers of species introduction, some of which are or become invasive and may 
spread from cities into surrounding landscapes [30]. Fragmentation and loss of habitats due to urban land use transformation create high edge-to-interior ratios in urban forest patches [31], increasing the permeability of these forests to dispersal of invasive plants. Linear forest strips, such as buffers along waterways and roads, are particularly susceptible [32]. Invasive plant species can not only reduce native biodiversity and the resources available to wildlife, but in the case of invasive vines in urban and suburban forests, they can increase tree mortality and prevent forest regeneration [33], often in concert with high abundance of herbivores in urbanized regions where predators have been extirpated [34].

The goal of this study was to understand the extent of riparian buffer forests vulnerable to urbanization, invasive species, and sea level rise impacts (hereafter, "squeezed forests") that have the potential to alter ecosystem function and health. We conducted a spatial analysis to model the extent and location of these stressors in urban and suburban environments and identified forested areas of greatest vulnerability to urbanization pressures, sea level rise, and storm surge. Preliminary observations indicated that invasive plants are widespread in these forests, but existing records of invasive plant species abundance were not spatially contiguous. To understand the extent and impact of invasive plant pressure, we conducted field sampling of forest composition, forest structure, and local-scale human impacts.

This research addresses existing information gaps at the intersection of multiple large-scale causes of ecosystem change. We asked the following questions:

What is the spatial extent of forests squeezed by urban land use and potential loss to sea level rise and storm surge? Coastal areas of the eastern United States are affected by increasing urbanization, rising sea levels, and increasing inland impacts of storm surges. Estuarine and riverine forests that serve important buffer functions are threatened by both. We expected forests affected by these combined stressors to be common across the study area, and we expected that these forests would also be impacted by invasive plants.

Does non-native plant invasion vary with differences in landscape context and disturbance? Land use and land cover surrounding forest patches influences their composition in complex ways, including species introductions, isolation of populations in habitats, and local microclimate alteration. We expect plant communities of squeezed forests to exhibit effects of local human impacts, surrounding conditions, and land use and land cover adjacent to the forest patch, such as high rates of invasive plant cover and indicators of human use and human-caused ecological disturbance.

\section{Study Area}

The urbanized coastal mid-Atlantic region of the United States sits at the intersection of these major forces of ecological change. This segment of the Eastern Seaboard is home to more than 40 million people in a dense matrix of cities and towns stretching along the Atlantic coast between Virginia and New Jersey, including Philadelphia, Washington, Wilmington, Trenton, and Baltimore (Figure 2). The region has experienced a long-term trend of population growth. From 2000 to 2010 (the most recent census period), Delaware's population increased by $14.6 \%$ (114,334 people), Virginia's by $13 \%$ (922,509), Maryland's by $9 \%(477,066)$, Pennsylvania's by $3.4 \%(421,325)$, and New Jersey's by $4.5 \%$ (377,544 people) [35]. Population centers are clustered along the coastline, and urban and suburban development has increased in coastal areas at a faster pace than inland. Urban land use transformation in the United States is projected to result in loss of ca. $118,000 \mathrm{~km}^{2}$ of forest by 2050 , with states in this region already exhibiting the nation's highest rates of urbanization and one-New Jersey-to become more than $50 \%$ urban land [36].

The mid-Atlantic region also contains two large biologically and economically important estuarine systems: the Chesapeake and Delaware Bays. This study is focused on forest patches within the boundaries of the Chesapeake and Delaware Bay watersheds (Figures 2 and 3), which together drain an area of nearly ten million hectares. In the Chesapeake Bay watershed, one-third of urban development land use transformation in recent decades has resulted in forest loss, and the fastest-growing urban areas surrounded by forested land have experienced the most loss of forest to impervious surfaces [37]. 


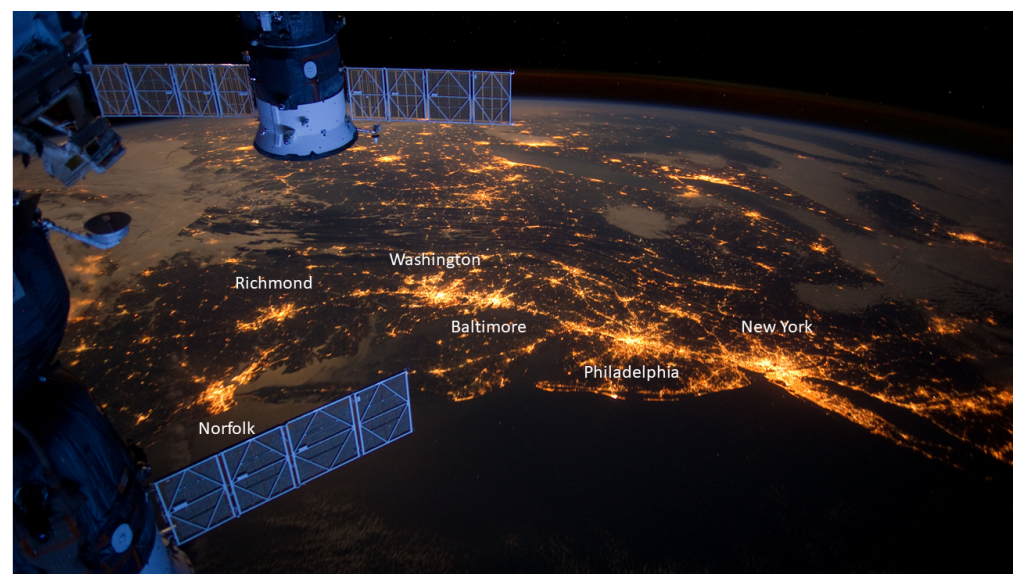

Figure 2. The Northeastern United States "Megalopolis", as seen from space at night. Our study area incorporates municipalities in the watersheds of two major bays—-the Delaware and the Chesapeake-and includes cities from Norfolk to Philadelphia. The Delmarva peninsula, which separates the two bays, extends below Baltimore in this photo toward Norfolk and is partially covered by a solar panel. Image credit: U.S. National Aeronautics and Space Administration (NASA), International Space Station.

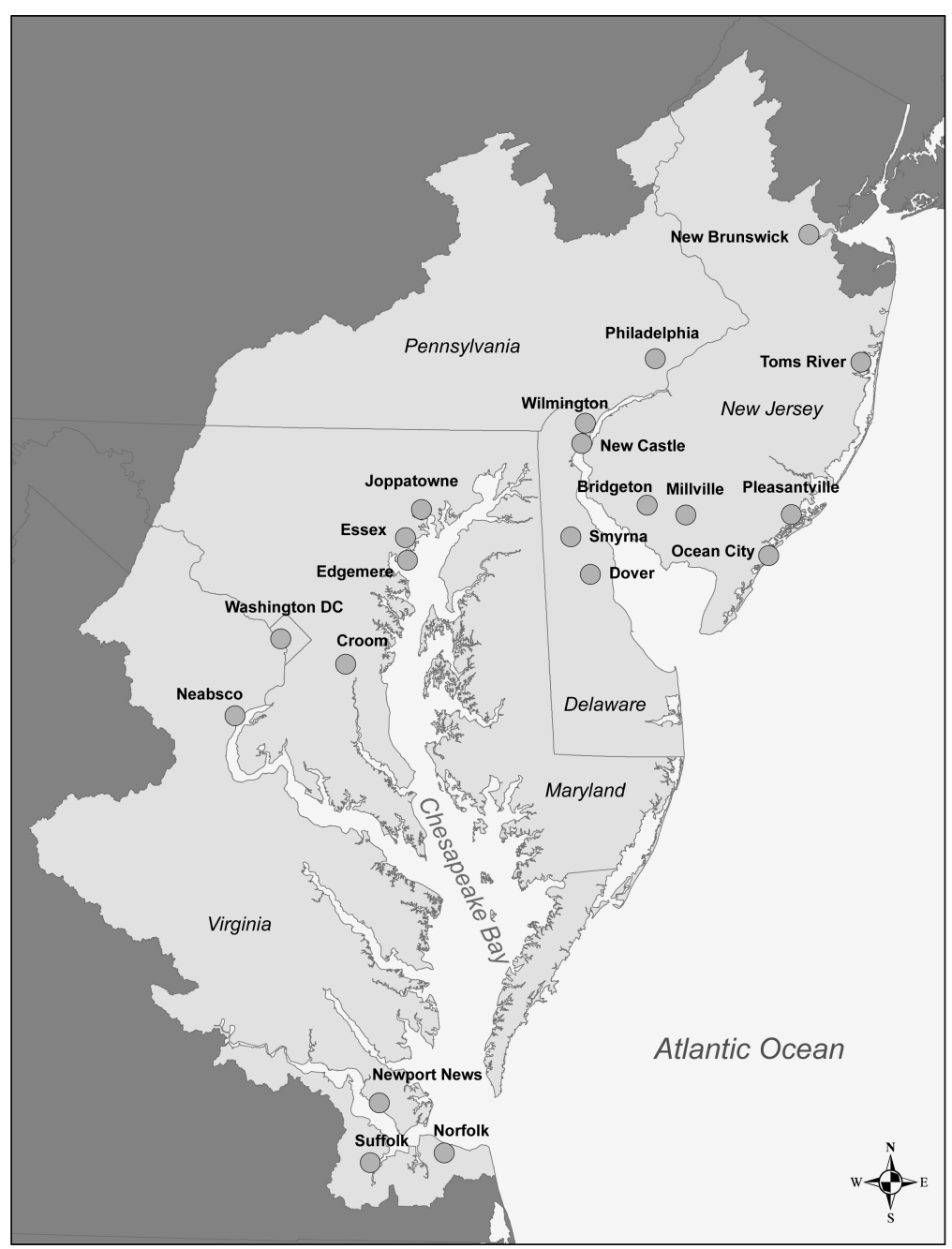

Figure 3. Study area (light gray land area) and location (gray circles) of sampled municipalities. The study region encompasses the watersheds of the Chesapeake and Delaware Bays. 
This region is also particularly vulnerable to climate change. On the Delmarva Peninsula, which sits between the Chesapeake Bay and Delaware Bay and is shared by the states of Delaware, Maryland, and Virginia, sea level rise is compounded by land subsidence. The peninsula has been sinking at the rate of $1.3 \mathrm{~mm}$ per year for the last 1000 to 2000 years [38]. Consequently, while global sea levels have risen $4-8$ inches in the last century, the peninsula's relative sea level rise (including land subsidence) was approximately 12 inches and projections are that the effective sea level rise may be up to an additional 2 to 5 feet in the next 100 years [39].

\section{Materials and Methods}

To understand the degree to which riparian forests are vulnerable to interactive effects of these combined stressors, we examined riparian forest patches likely to be affected by storm surge and sea level rise along a gradient of city size. We conducted analyses at landscape, forest patch, and plot scales. First, we used geospatial data to estimate the extent of forest patches likely to be affected by multiple stressors under varying scenarios of sea level rise at a regional scale. We then selected and sampled 100 sites that would be affected by storm surge under the most conservative model. In these sites, we examined vegetation and indicators of disturbance at a plot scale.

\subsection{Squeeze Modeling}

To assess the potential extent of urban riparian forests vulnerable to simultaneous stresses of urbanization, sea level rise, and storm surge in this region, we integrated national land use and land cover data with inundation risk modeling.

\subsubsection{Modeling Urbanization and Forest Extent}

ESRI ArcGIS ${ }^{\circledR}$ 10.5.1 software [40] was used to store and analyze over 350 GB of geospatial data. Using the Watershed Boundary Dataset [41], we delineated watersheds draining into Delaware Bay and the Chesapeake Bay for geospatial analyses, comprising a total study area of 9,829,678 ha. We used the U.S. National Landcover Database (NLCD) 2011 land cover product [42] to identify forest patches adjacent to urban development. Selected forest patches were located within $500 \mathrm{~m}$ of areas classified by NLCD (2011) as Developed Medium Intensity (impervious surface cover 50-79\%, commonly including medium to high density single-family housing units) or Developed High Intensity (impervious surface cover $80-100 \%$, commonly including apartment complexes, row houses and commercial/industrial areas). Minimum forest patch size was set at 0.1 ha $(0.25 \mathrm{ac})$, following [43]; for context, this is also the size of an average American suburban residential yard. Forest type classes included Deciduous Forest, Evergreen Forest, Mixed Forest, and Woody Wetlands. From this analysis, we derived the number, size, and public v. private ownership of forest patches. We also derived land cover type within a $500 \mathrm{~m}$ buffer of sites selected for ground sampling, and proportional and absolute perimeter adjoining land cover types of each forest patch. Additional land cover types included Cultivated Crops, Developed Open Space, Hay/Pasture, Emergent Herbaceous vegetation, Shrub/Scrub vegetation, and Barren Land (NLCD 2011).

\subsubsection{Modeling Sea Level Rise and Storm Surge Vulnerability}

To model the combined stressors of sea level rise and storm surge, we synthesized four datasets: a Digital Elevation Model (DEM) of the area, storm surge surface models, sea level rise surface models, and the National Hydrography Dataset. To estimate storm surge, we merged Sea, Lake, and Overland Surges from Hurricanes (SLOSH) storm surface models for New York, Delaware Bay, and Chesapeake Bay basins [44-46]. Ordinary kriging was used to extend the storm surge surface inland, and $10 \mathrm{~m}$ rasters estimating storm surges for category 1,2, and 4 hurricane events were generated. Sea level rise (SLR) was estimated from a DEM mosaic of the NOAA Coastal Services Center Coastal Inundation Digital Elevation Model [47] and the US Geological Survey standard DEM 1/9 arc-second product [48] resampled to $10 \mathrm{~m}$ using cubic convolution. Sea level rise was estimated for $0.0 \mathrm{~m}, 0.6 \mathrm{~m}$, and $1.8 \mathrm{~m}$ sea 
level rise scenarios. By combining these layers, 9 storm surge-sea level rise surfaces were generated (Cat 1,2 , and 4 storms) $\times(0.0 \mathrm{~m}, 0.6 \mathrm{~m}$, and $1.8 \mathrm{~m} \mathrm{SLR})$.

Initial inundation extent was estimated by subtracting DEM values from storm surge/sea level rise surfaces. This initial output was evaluated for connectivity (inundation) using an 8 sided neighborhood rule and connected cells were extracted. Area water features identified in the National Hydrography Dataset [49] were dissolved and converted to a $10 \mathrm{~m}$ raster. This layer and areas of land not typically inundated derived from the DEM hydrologic break lines were combined to form a mask to extract connected cells. Inundated areas with less than $95 \%$ confidence were removed to form the final inundation extents.

We note that the resulting model is a "gentle flooding model" (water rises and covers) - no effort was made to model backpressure effects-and inundation is shown as it would appear during the mean high tides (excludes wind driven tides). We also did not account for erosion/deposition, subsidence/uplift, future changes in hydrodynamics, or preexisting conditions such as soil moisture and river input.

\subsection{Field Rapid Assessment of Stressors and Forest Conditions}

To determine the extent and intensity of invasive plant pressure on forests vulnerable to urbanization and flooding due to storm surge and sea level rise, we conducted a rapid field assessment. This assessment also documented evidence of human activity and non-human ecological disturbances.

\subsubsection{Selection and Location of Sampling Points}

We selected 20 municipalities representing the range of municipality sizes occurring in the study region (Figure 3 and Table A1) and located 5 points in each municipality (total: 100 sites) for field-based measurement of invasive plant species, vegetation composition and structure, and indicators of impact from human management and use. Selected sites were located on public lands to facilitate access for observation. To identify areas of greatest potential vulnerability to combined stressors, forest patches were selected based on adjacent urbanization and potential inundation modeling. Adjacent urbanization was defined using NLCD 2011 [42] as described in Section 2.1.1. above. Sampling points were located within the boundary of the most conservative scenario for storm surge and sea level rise: Category 1 hurricane storm surge with no (zero) sea level rise; these locations would be inundated under all scenarios. Center points of sampling plots were randomly assigned within these patches, including additional points for use when encountering barriers preventing access to a coordinate. Field technicians located sampling points using GPS. Where the location of a coordinate in the field was not entirely inside a forest patch due to error inherent in remote sensing and/or change in patch boundaries, plot center was relocated to the interior of the forest patch.

\subsubsection{Field Sampling: Vegetation}

Circular plots of $400 \mathrm{~m}^{2}$ (11.3 m radius) were established around the randomized coordinates. A laser hypsometer was used to determine plot boundary. In each plot, all trees $>2.5 \mathrm{~cm}$ diameter were identified to species. Greatest degree of vine coverage on trees, dominant vine species, dominant herbaceous species, and indicators of disturbance were recorded for the entire plot. Degree of vine coverage was based on the Schumaker vine invasion index [50]. Categories of coverage were: 0: no lianas climbing trees, 1: vines at the base of tree bole, 2: vines covering tree bole, 3: partial canopy coverage, and 4: complete canopy coverage. In a $20 \mathrm{~m}^{2}$ circular subplot at the center of each plot, ground layer cover of all species was visually estimated using $1 / 8$ radial increments. Within subplots, individual trees of all size classes (including seedlings $<1 \mathrm{~m}$ in height and saplings $>1 \mathrm{~m}$ in height and $<2.5 \mathrm{~cm} \mathrm{DBH}$ ) and all shrub stems emerging from the ground were counted and identified. Species were categorized as native or non-native to the mid-Atlantic region following the USDA PLANTS Database [51]. Non-native species were categorized as invasive if they appeared on a state 
invasive plant list of one of the states in the study region [52-56]. All invasive species were non-native. Field identification followed [55,57-60]; taxonomy follows USDA PLANTS Database [51].

\subsubsection{Field Sampling: Disturbance Indicators}

Indicators of human and non-human ecological disturbance were developed from regional and urban assessments of environmental impact and were designed to be compatible with these measures for cross-comparability. These included assessments utilized in rural riparian and forest systems [61-64], assessments used by urban land managers [65-68], studies examining human impacts on urban forest systems [10,69], and indicators of non-human forest disturbance [70,71]. Evidence of human activity included vegetation manipulation such as cutting or planting; dumping or accumulation of household waste; digging, shoreline alteration, and earth moving; trails, roads, and trampling; recreational equipment and camping; fencing; and building. Non-human disturbances included canopy gaps due to fallen trees and high levels of herbivory. High abundance of white-tailed deer (Odocoileus virginicus) in the region can affect forest regeneration [34,72-75], so signs of deer (e.g., tracks, browse, scat) were also recorded.

\subsection{Statistical Analysis}

Statistical analyses were performed in R version 3.6.1 (R Core Team, 2016). All tests for significance are reported at the $\alpha=0.05$ critical value, and, in a few cases, the $\alpha<0.10$ critical value is reported to identify potential trends. Pearson correlation analysis was used to assess whether the species richness of invasive vines present correlated with the intensity of vine coverage (trunk and canopy cover) across forest patches. To assess the influence of local human activities on invasive plant species, we performed bivariate linear regression analysis between the abundance of invasive trees, saplings, seedlings, shrubs, or total species and the observable signs of natural and human disturbance within forest plots. To assess human influences on invasive plant abundance across spatial scales, we performed pairwise linear regression analysis between the richness of invasive plants or total number of invasive plant species by growth form (i.e., tree, shrub, vine, forb, graminoid) and (1) the proportion of urban, agricultural, and forest land use/land cover within $500 \mathrm{~m}$ of the forest plot center, (2) the proportion of urban, agricultural, and forest land use/land cover adjacent to the forest patch (i.e., along forest perimeter), and (3) the municipal population size for each city. Finally, we assessed the relationship between total municipal population for each city and (1) the richness of invasive plants, (2) the total number of invasive plant species by growth form, and (3) the abundance of invasive trees, saplings, seedlings, or shrubs and the total municipal population for each city using linear regression analysis.

\section{Results}

\subsection{Spatial Extent}

The results of this analysis reveal that many forest patches in the study area are vulnerable to combined stressors, and that these vulnerable forests comprise a significant proportion of the forested area in this urbanized region. The watersheds of the Chesapeake and Delaware Bays contained 443,968 forest patches greater than $0.1 \mathrm{ha}(0.25 \mathrm{ac})$ in size, covering an area of 3,292,290 ha $\left(12,711 \mathrm{mi}^{2}\right)$, $41 \%$ of the land surface area of the study region (Table 1). They ranged in size from 0.6 to 370,719 ha, with a mean area of 74 ha but a median of only 1.8 ha.

Most forest patches in the region (280,275 patches; $63 \%)$ were bordered by high- or medium-density urban development. Forest patches adjacent to urban development spanned the entire range of forest patch size in the region and comprised $92 \%$ of forested land.

Under the most-likely near-term future scenario, in which a Category 1 hurricane makes landfall in the study area, storm surge would affect 33,443 (8\%) of the region's urban-adjacent forest patches and inundate $5 \%$ of regional forest land area (Figure 4). With the larger storm surge of a Category 2 hurricane, $10 \%$ of regional forest patches would experience flooding, and $9 \%$ of the regional forest area (3,060,297 ha) would be inundated. 
Table 1. Proportional cover by land cover class in the Chesapeake and Delaware Bay watersheds, excluding open water. Forest land cover classes include deciduous, evergreen, mixed, and woody wetlands.

\begin{tabular}{ccc}
\hline Land Cover Type & Area (ha) & $\%$ \\
\hline Forest & $3,292,290$ & $41.4 \%$ \\
Cultivated Crops & $1,338,872$ & $16.8 \%$ \\
Developed, Open Space & 936,933 & $11.8 \%$ \\
Hay/Pasture & 837,969 & $10.5 \%$ \\
Developed, Low Intensity & 506,997 & $6.4 \%$ \\
Developed, Medium and High Intensity & 361,724 & $4.5 \%$ \\
Emergent Herbaceous Wetlands & 301,778 & $3.8 \%$ \\
Shrub/Scrub & 284,936 & $3.6 \%$ \\
Herbaceous & 59,406 & $0.7 \%$ \\
Barren Land & 40,217 & $0.5 \%$ \\
Total & $7,961,121$ & $100 \%$ \\
\hline
\end{tabular}

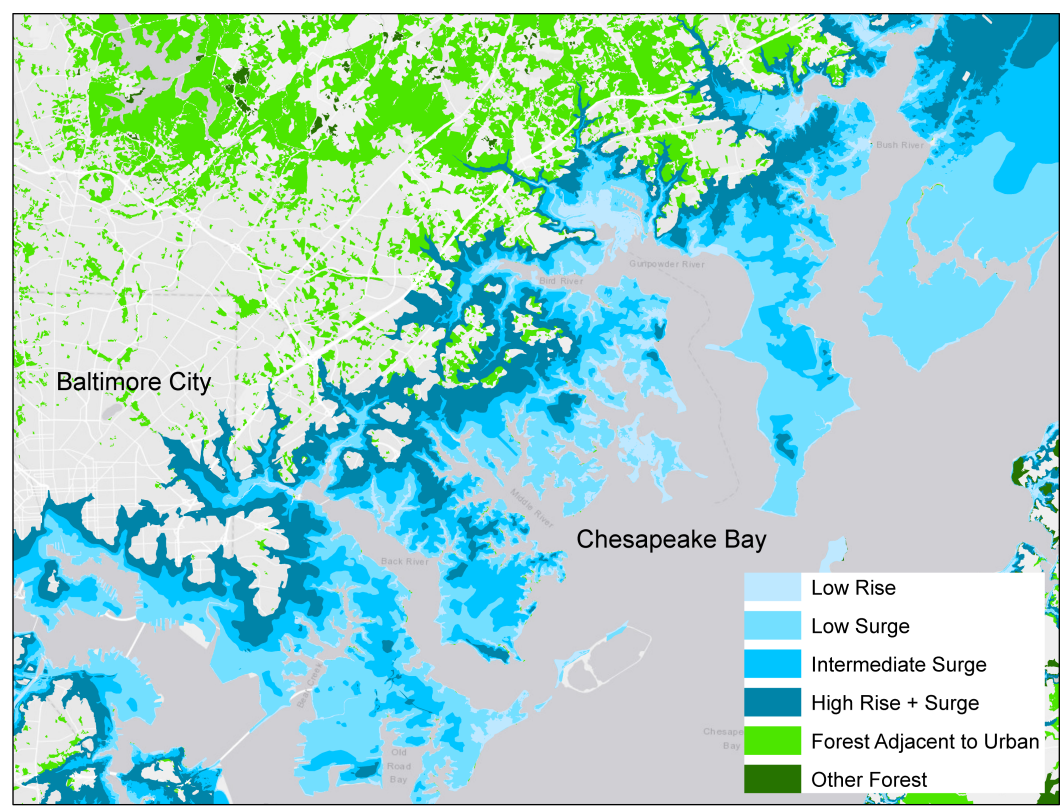

Figure 4. Inundation modeling under scenarios of storm surge and sea level rise. Darker blues indicate more extreme scenarios. Low Rise: $0.6 \mathrm{~m}$ sea level rise (SLR); Low Surge: Category 1 hurricane storm surge (SS); Intermediate Surge: Category 2 SS; High Rise + Surge: 1.8 m SLR with Category 4 SLR.

Under the lower sea level rise scenario without storm surge, 21,170 urban-adjacent forest patches would lose area to the rising sea. The flooded area ( $602,478 \mathrm{ha}$ ) would comprise $2 \%$ of the region's forests. Under the maximum sea level rise and storm surge parameters (6 ft sea level rise combined with Category 4 hurricane storm surge), $14 \%$ of regional forest patches would be affected, and $19 \%$ of regional forest land $\left(6,169,628 \mathrm{ha}\right.$, or $\left.23,821 \mathrm{mi}^{2}\right)$ is projected to go underwater.

\subsection{Plant Community Composition}

In forests squeezed by urbanization and sea level rise, patterns of species richness and composition differed among plant growth forms and forest layers. The forest layers with the most invasive plants were the shrub layer (where invasive plants were present in $61 \%$ of forests) and woody climbing vines (present in $83 \%$ of forests). We identified 92 species of trees including 88 species of trees $>$ $2.5 \mathrm{~cm} \mathrm{DBH}, 39$ species of tree saplings ( $>1 \mathrm{~m}$ in height and $<2.5 \mathrm{~cm} \mathrm{DBH}$ ), and 69 species of tree seedlings ( $<1 \mathrm{~m}$ in height); 28 species of vines, 72 species of forbs, 10 graminoids, and 42 shrub species. The majority of individual trees (94\%), tree saplings (92\%), and tree seedlings $(90 \%)$ were native species (Figure A1), whereas over half of the shrubs found across the forests were invasive species (52\%; 
Figure 5; Figure A1). We observed at least one invasive plant species in almost every forest plot (94\% of forest plots; Figure 6).

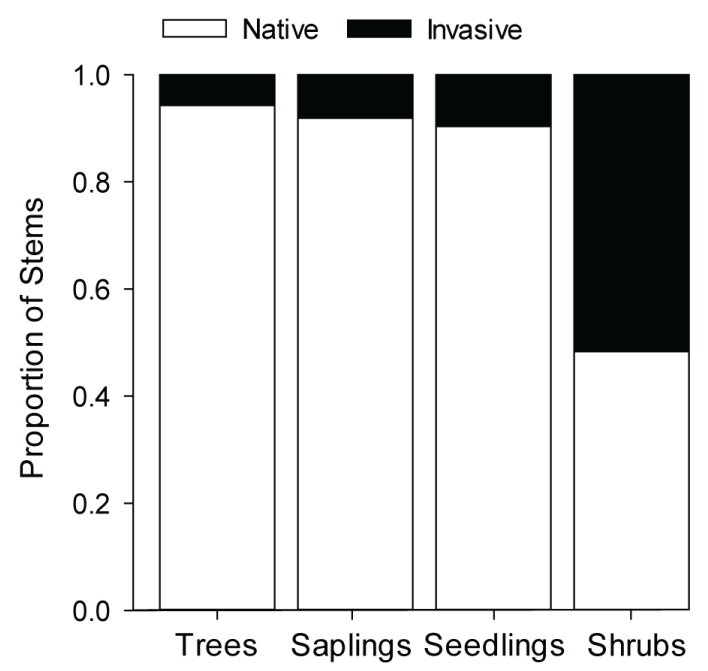

Figure 5. The proportional abundance of total woody plant stems by growth form belonging to non-native invasive species (black) and native species (white) across 100 forest patches in the Chesapeake and Delaware Bay watersheds of the mid-Atlantic coast of the United States.

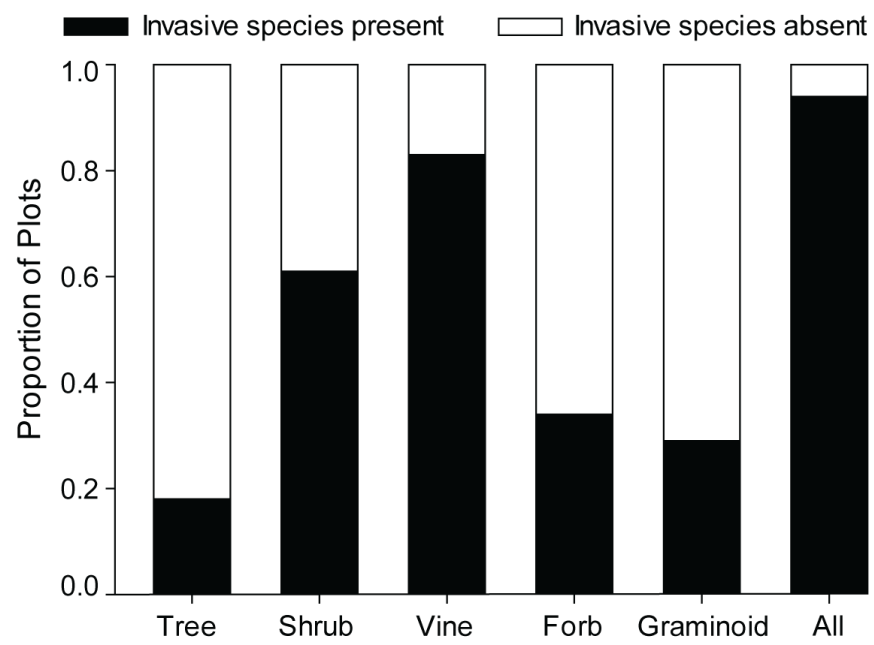

Figure 6. The proportion of plots containing invasive plants across plant growth forms (trees, shrubs, vines, forbs, and graminoids) and the total number of plots containing invasive plants of any growth form.

\subsubsection{Trees}

While the majority of canopy trees $>2.5 \mathrm{~cm}$ DBH were native, the most abundant non-native trees encountered in both the canopy and in recruiting size classes would be familiar to managers of urban forests of the region (Figure A1). These include widely planted street trees and ornamental introductions from temperate Asia, among them the cosmopolitan tree-of-heaven (Ailanthus altissima), regionally spreading ornamental hybrid Callery pear (Pyrus calleryana), Norway maple (Acer platanoides), mimosa (Albizia julibrissin), white mulberry (Morus alba), bird cherry (Prunus avium), and princess tree (Paulownia tomentosa). All non-native trees sampled were listed as invasive plants in one or more states in the study region, with the exception of Ginkgo biloba.

The most frequently observed mature tree species were native (Acer rubrum, $50 \%$ of plots; Prunus serotina, $41 \%$ of plots). The most abundant tree (Acer rubrum, 335 stems across all plots) was 
native (Figure A1). Invasive trees were found in $18 \%$ of forest plots and the most frequent invasive tree was Ailanthus altissima ( $8 \%$ of plots).

\subsubsection{Tree Seedlings and Saplings}

The most frequently observed canopy tree saplings (Liquidambar styraciflua and Prunus serotina, found in 5\% of plots) and canopy tree seedlings (Prunus serotina, 27\% of plots; Acer rubrum, $24 \%$ of plots) were native species. The most abundant sapling (Ostrya virginiana, 15 stems across all plots) and seedling (Acer rubrum, 385 stems across all plots) were also native species (Figure A1). However, we found that not all forest plots contained native saplings; $77 \%$ had seedlings and only $30 \%$ had saplings of native tree species. Almost one quarter (24\%) of plots contained invasive trees, yet regeneration and recruitment of invasive trees was observed in fewer forest patches (non-native seedlings: $18 \%$ of plots; non-native saplings: $5 \%$ of plots).

\subsubsection{Shrubs}

Invasive shrubs occurred in $61 \%$ of forest plots. The shrub layer of "squeezed" forests contained an assortment of regionally common invasive species introduced from temperate climate zones of Europe and Asia. These included the shrub honeysuckles Amur honeysuckle (Lonicera maackii, 416 total stems across all plots) and Morrow's honeysuckle (Lonicera morrowii), privets (Ligustrum sinense and L. vulgaris), multiflora rose (Rosa multiflora), Japanese knotweed (Fallopia japonica), autumn olive (Elaeagnus umbellata), wineberry (Rubus phoenicolasius), and burning bush (Euonymus alatus), in order of rank abundance (Figure A1). The most frequently encountered shrub, Rosa multiflora (found in $33 \%$ of plots), was a non-native, invasive species. However, the second most frequently encountered shrub species, Lindera benzoin and Viburnum dentatum (found in 18\% of plots), were native. More than two-thirds (78\%) of the invasive woody plants identified were invasive shrub species.

\subsubsection{Vines}

The most common invasive plants were vines; invasive woody vines were found in $83 \%$ of forest plots. Japanese honeysuckle (Lonicera japonica) was the most frequent of these ( $54 \%$ of plots) followed by Hedera helix (33\% of plots), Celastrus orbiculatus ( $28 \%$ of plots), and Ampelopsis brevipedunculata ( $20 \%$ of plots). Other vine species were found in few plots (1-7\% of plots). Most forest patches $(81 \%)$ had woody vines growing on the trees, and two-thirds of plots $(66 \%)$ had vines covering entire tree trunks and covering a quarter or more of tree canopies (Figure 7). There was a significant positive correlation between the species richness of invasive vines present and the degree of vine coverage on trees $(R=0.31, p=0.002)$.

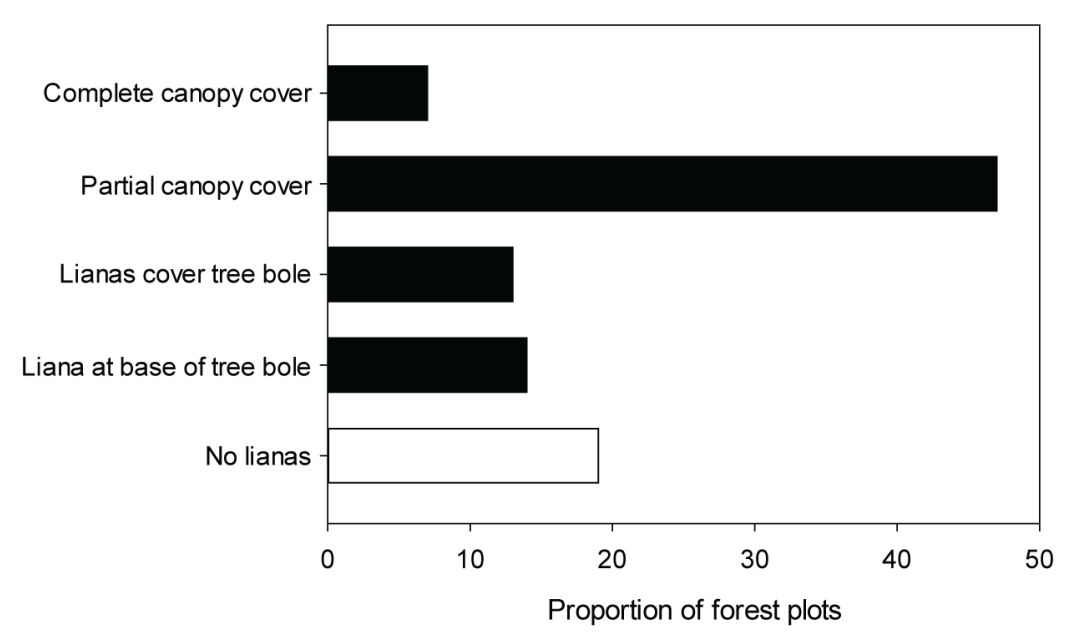

Figure 7. Proportion of forest plots by degree of maximum woody vine cover on trees. Forest plots with no vines are shown in white, and plots with vines are shown in black. 


\subsubsection{Forbs and Graminoids}

Invasive forbs and graminoids were present in approximately one-third of forest plots ( $29 \%$ and $34 \%$ of plots, respectively; Figure A1). Microstegium vimineum (Japanese stilt grass) and Phragmites australis (common reed) were the most frequent invasive graminoids ( $23 \%$ and $7 \%$ of plots, respectively) and Glechoma hederacea (ground-ivy) and Alliaria petiolata (garlic mustard) were the most frequent invasive forbs ( $13 \%$ and $10 \%$ of plots, respectively).

\subsection{Effects of Landscape Context and Disturbance}

The potential for human-derived impacts to influence non-native plant invasion varies by spatial scale. Within each forest plot, we assessed we assessed presence or absence of signs of natural and human-caused disturbances (Table 2). The most frequent indicators of disturbance were human-derived, with visible signs of human activity occurring in $77 \%$ of the forest plots (Figure 8). The most frequent signs of human disturbance were vegetation manipulation (e.g., mowing), dumping, and garbage (Table 2), each of which occurred in greater than $60 \%$ of plots. Trails were encountered in $32 \%$ of plots. Disturbances not necessarily of human origin included canopy gaps caused by tree fall ( $29 \%$ of plots), erosion $(4 \%)$, and fire $(<1 \%)$. Signs of deer herbivory were observed in $46 \%$ of plots. While human-initiated ecological disturbances were common across our forest sites, we found no relationship between the number of different human disturbance types observed in a plot and the abundance of invasive saplings, seedlings, or shrubs, or total invasive woody plants. However, we found a significant positive relationship between the abundance of invasive trees and the number of visible signs of human disturbance in each forest plot $\left(\mathrm{r}^{2}=0.14, \mathrm{p}<0.001\right)$.

Table 2. Frequency of observed disturbance types.

\begin{tabular}{cc}
\hline Disturbance Category & Proportion of Sites \\
\hline Vegetation manipulation & 64 \\
Dumping & 63 \\
Garbage & 62 \\
Deer signs & 46 \\
Trail & 32 \\
Canopy gap due to fallen canopy tree & 29 \\
Other human activity & 18 \\
Gully erosion & 15 \\
Digging / Earth moving & 13 \\
Fencing & 13 \\
Trampling & 11 \\
Road & 9 \\
Recreational equipment & 5 \\
Building & 4 \\
Camping & 3 \\
None & 3 \\
Fire & 2 \\
Livestock grazing & 2 \\
\hline
\end{tabular}

\footnotetext{
${ }^{1}$ Deer signs included scat, browse, hoofprints, and browse line. ${ }^{2}$ Shoreline alterations included riprap/armoring, bulkhead, and solid fill pier.
}

Surrounding land use/land cover within $500 \mathrm{~m}$ of the center of our forest plots provides an indication of local landscape influences. Although weak, we found significant positive relationships between the proportion of the area surrounding each forest plot that was in agriculture and the richness of invasive plants $\left(\mathrm{r}^{2}=0.05, \mathrm{p}=0.03\right)$ and the total number of growth forms of invasive plants per plot $\left(r^{2}=0.05, p=0.02\right.$; Figure 9$)$. We found no relationships between differences in the proportion of forest or urban area within this radius and invasive plants (richness or number of growth forms); all plots had forest adjacent. All plots were located in patches adjacent to urban land, and $94 \%$ of plots had urban land use within $500 \mathrm{~m}$ of the sampling point. 


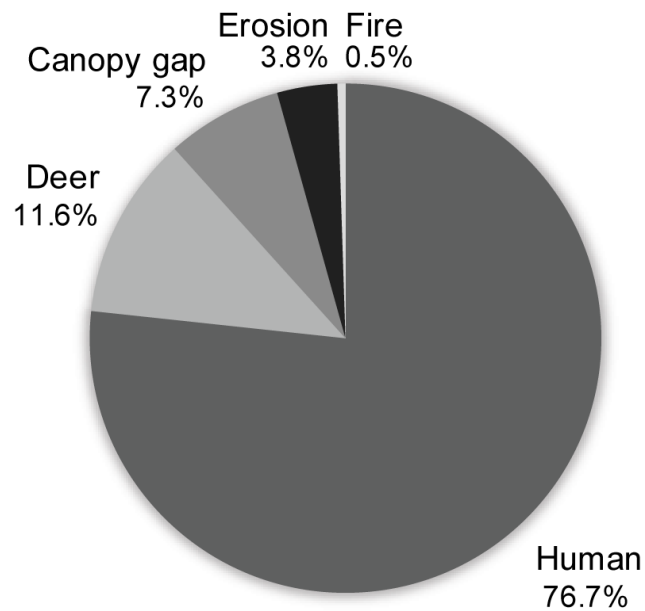

Figure 8. Frequency of observed disturbance by type. Most observed disturbance was of human origin, followed by evidence of deer browsing; canopy gaps due to tree fall; soil erosion; and fire.
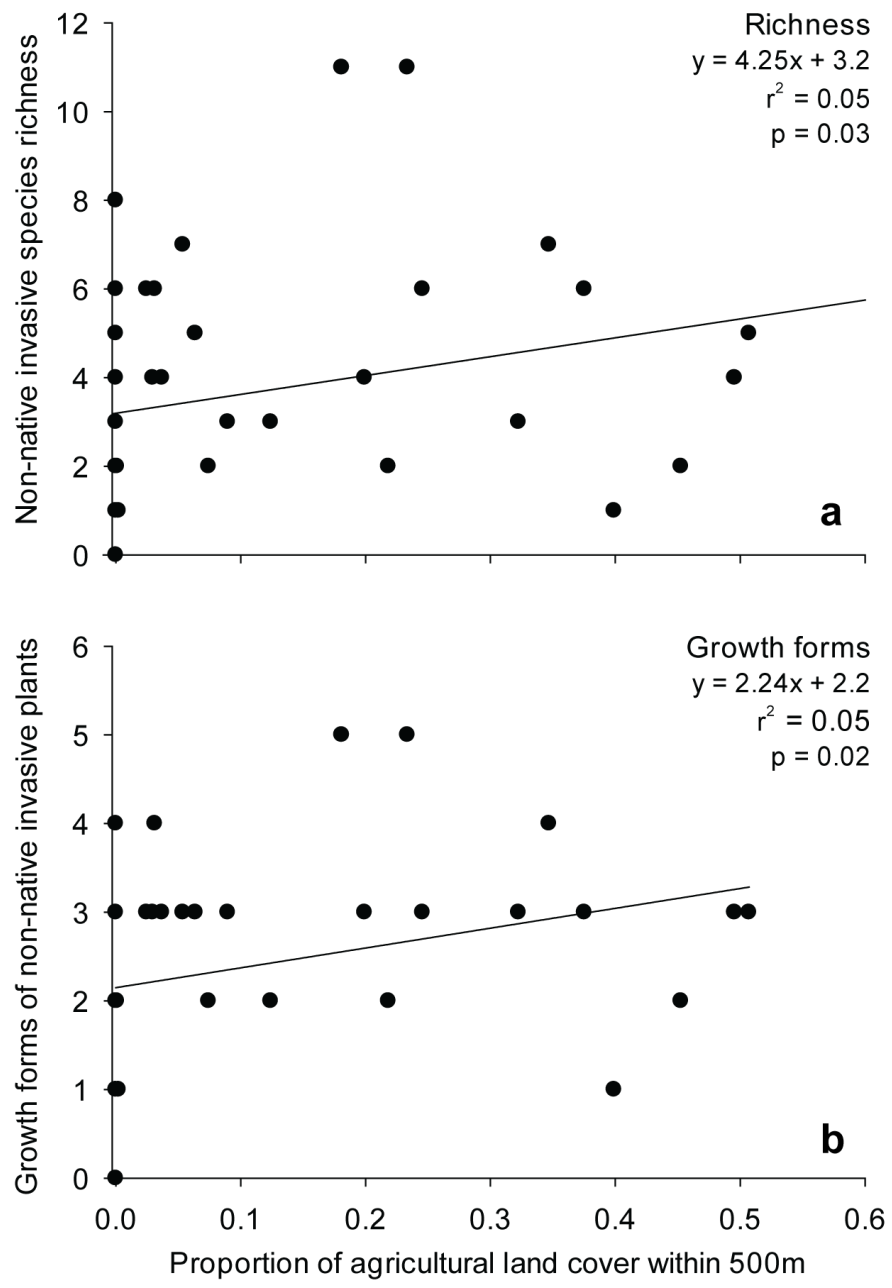

Figure 9. The (a) invasive plant species richness in each forest plot and (b) total number of growth forms of invasive plant species in each forest plot as a function of the proportion of agricultural land cover within $500 \mathrm{~m}$ of plot center. A greater diversity of growth forms indicates presence of invasive plants in multiple forest layers (i.e., herbaceous, shrub, tree, vine).

At the scale of the whole forest patch, land use/land cover adjacent to a forest patch (i.e., along the perimeter of the forest) had similar patterns in relation to invasive plants. The proportion of 
agricultural land cover adjacent to the forest patch had a significant positive relationship with the richness of invasive plants $\left(\mathrm{r}^{2}=0.12, \mathrm{p}<0.001\right)$ and number of growth forms of invasive plants $\left(r^{2}=0.08, p<0.01\right.$; Figure 10). We found no relationship between proportion of adjacent forest or urban development and invasive plants (richness or number of growth forms).
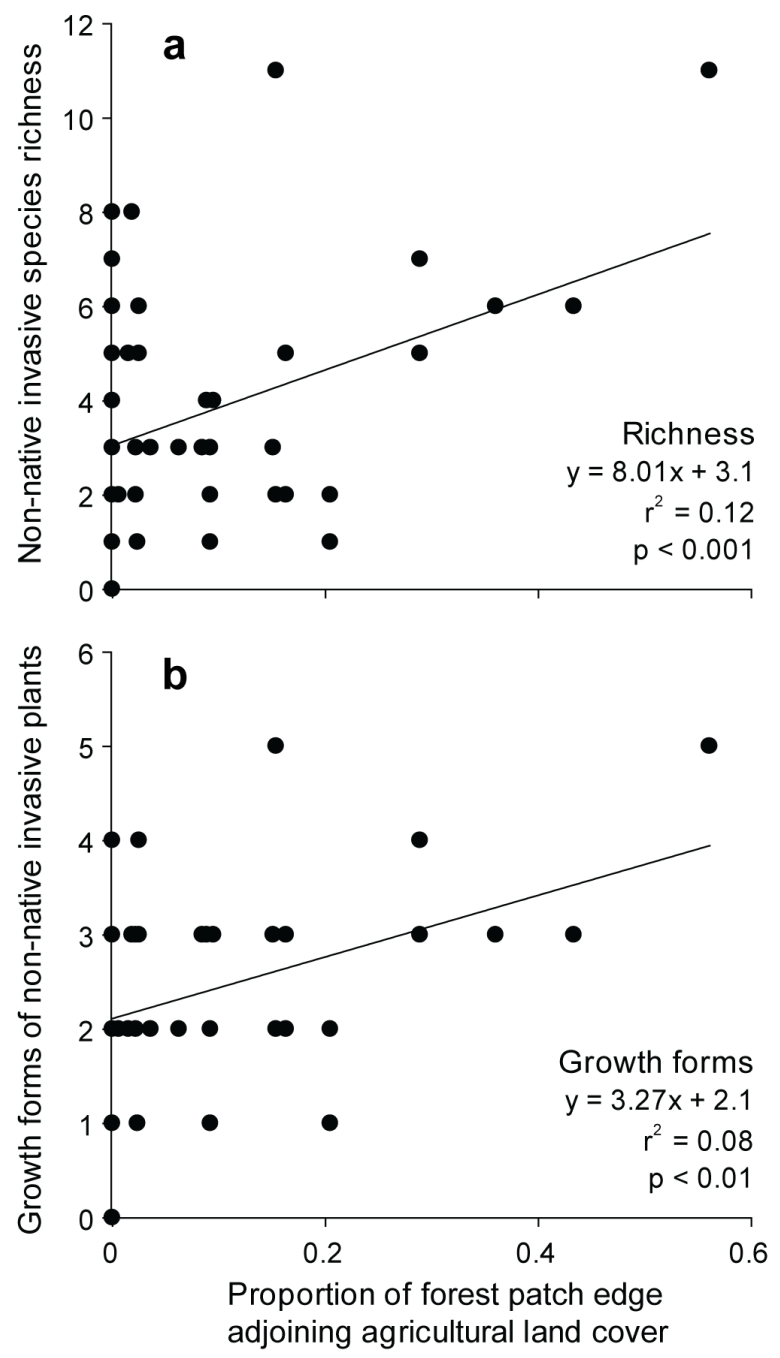

Figure 10. The (a) invasive plant species richness in each forest plot and (b) total number of growth forms of invasive plant species in each forest plot as a function of the proportion of the forest patch edge adjacent to agricultural land cover.

At the metropolitan scale, we found no significant relationships between municipal population size and the richness of invasive plants or total number of invasive plant species by growth form. We found a weak positive association between the total municipal population and the abundance of invasive trees $\left(r^{2}=0.15, p=0.09\right)$. However, this pattern was driven by one forest in Philadelphia that contained multiple invasive trees, such as Acer platanoides, Ailanthus altissima, and Morus alba. There were no significant relationships between municipal population size and the abundance of invasive saplings, seedlings, or shrubs.

\section{Discussion}

This research provides a first essential step in understanding the extent to which urban riparian forests are vulnerable to three significant stressors (urbanization, plant invasion, and sea level rise) that ultimately influence ecosystem health and function. 


\subsection{Spatial Patterns}

Our analysis reveals that forests are threatened by urbanization and sea level rise throughout the densely populated central mid-Atlantic coast of the United States. In the Chesapeake Bay and Delaware Bay watersheds, nearly two-thirds of forest patches are bordered by medium- or high-density urban development. Under the most conservative climate change scenario-no sea level rise and a Category 1 hurricane- $8 \%$ of the region's forests would be inundated by storm surge. Under the most likely projection for sea level rise, $2 \%$ of the region's forests would be permanently flooded, whereas under the maximum sea level rise and hurricane projection, nearly a fifth of regional forest land would flood. These results indicate that a large proportion of the region's forests adjacent to urban development are vulnerable to changes in sea level and increasing storm severity. These low-lying forests are relied upon to support biodiversity and buffer land-based pollution from harming aquatic life in these highly productive and economically important bays.

\subsection{Forest Condition}

Forests threatened by rising waters and urbanization are also affected by non-native plant invasion, as indicated by our field sampling of 100 forest sites across the study region. More than two-thirds of the invasive plants in these forests were shrubs, and invasive vines were found in more than $80 \%$ of sampled sites. The health of these forests is compromised by these non-native woody vines [33], which we observed both as dense ground layer cover (as in the case of Lonicera japonica) and covering tree canopies (e.g., Celastrus orbiculatus and Ampelopsis brevipedunculata). Two-thirds of sampled forests had invasive woody vines in the tree canopy. These results suggest that urban forests threatened by sea level rise and storm surge are also experiencing internal pressures from non-native plant invasion.

The exception to the pattern of invasive plant dominance was the canopy tree layer of the forest, which was dominated by native species. The most abundant tree species are a regionally common set of early pioneer species that colonize following ecological disturbance, indicating that these sites have been colonized relatively recently. Further investigation could reveal whether there are regional patterns of historic land use change influencing the current condition of these forests. Interestingly, many of the most common trees were species typical of uplands rather than wetland or riparian zones. This could indicate effects of flashy hydrology typical of urban environments and runoff from impervious surfaces, which erode streams and can restrict access of floodwaters to floodplains in a cycle of deepening incision [76]. Flood plain dissipation of storm flows and infiltration of both water and pollutants is an important buffering function of riparian streams that may be compromised.

\subsection{Drivers of Forest Conditions}

Forests threatened by rising waters and urbanization are also subject to more direct human-caused ecological disturbance, which we observed in more than three quarters of sites sampled. Much of this disturbance involved manipulation of vegetation such as mowing, pruning, and tree cutting; the other most common disturbance was dumping of household and yard waste. Abundance of non-native trees was correlated with these types of human disturbances.

Forest patch configuration, although not explored here, may also be an important driver of human-caused ecological disturbance and vulnerability to invasive plant species [77]. Signs of high abundance of white-tailed deer (Odocoileus virginicus) were also frequently observed. Populations of this important browsing herbivore are currently many times larger than historical estimates due to predator extirpation and increase in favorable forest edge habitats [78], and many urban deer populations have lost human avoidance behavior.

One limitation of this study is the fact of a limited observation window over time and space; our observations here are likely influenced by processes occurring across temporal and spatial scales that are not directly considered $[79,80]$. For example, legacies of species introduction by agriculture are a little-considered but potentially very important driver of urban plant community composition. 
Urbanization often transforms agricultural lands to urban land use as cities grow beyond their starting points into surrounding supporting land uses. We found weak associations between adjacent agriculture and both the species richness and variety of growth forms of non-native invasive plants. Influence of land use history and the scale of landscape change processes on ecosystem change are increasingly recognized to be important and are likely to be at play here. Our focus in this study is to draw attention to the interacting stressors on streamside forests but gaining a better understanding of ecological drivers in future work will necessitate an explicit treatment of temporal and spatial scale.

\section{Conclusions}

Here, we have established the spatial extent of forests currently under broad-scale environmental pressures in a major urban region that spans two large and productive estuarine bays, and revealed the role of invasive plants in these forests. By encompassing three major sources of ecosystem change, we provide new insight into how the interaction of these stressors might affect the function of urban riparian buffers, and potential for change. Our results emphasize the importance of protection and restoration of forests in urban regions and point to areas for future work.

Both urbanization pressures and human-caused ecological disturbances are most appropriately understood as part of a social-ecological system. Here, field data from publicly owned forest patches demonstrate impacts of multiple stressors. This approach could be extended to include forests under private ownership to better understand the influence of fine-scale management decision making. Collaboration with social scientists to identify social drivers of decision making at the scale of individual properties that affect buffer function and perception of buffer management, combined with identification of appropriate conservation and management targets for urban riparian buffer forests, would speed development of new approaches to buffer edge management. The integration of environmental and social benefits with improved buffer condition and function can maximize function for habitat and water quality while meeting the needs of urban communities.

In highly urban regions, remnant, regenerating, and emerging riparian ecosystems are simultaneously subject to the multiple stressors of rising seas, increasingly strong storms, urban development, and invasive species spread. While inland development limits their extent and alters their condition, sea level rise squeezes these forest patches from the shore, and invasive plants cover forest canopies and suppress tree regeneration. Where pressures combine, there is a greater likelihood of loss of habitat and water quality buffer functions but also greater opportunity and potential for effective management to mitigate the loss.

Author Contributions: Conceptualization, L.R.J. and T.L.E.T.; methodology, L.R.J., T.L.E.T., T.J.B., C.J., and S.D.; software, T.L.E.T. and C.J.; validation, L.R.J., T.L.E.T., and C.J.; formal analysis, L.R.J., T.L.E.T., T.J.B., J.B., and C.J.; investigation, L.R.J., T.L.E.T., T.J.B., J.B., and C.J.; resources, L.R.J., T.L.E.T., T.J.B., and C.J.; data curation, L.R.J., T.L.E.T., T.J.B., and C.J.; writing-original draft preparation, L.R.J., T.L.E.T., T.J.B., and C.J.; writing-review and editing, L.R.J., T.L.E.T., T.J.B., J.B., S.D., and C.J.; visualization, T.J.B., T.L.E.T. and L.R.J.; supervision, L.R.J. and T.L.E.T.; project administration, L.R.J. and T.L.E.T.; funding acquisition, L.R.J., T.J.B., T.L.E.T., and C.J. All authors have read and agreed to the published version of the manuscript.

Funding: This research was funded by the Delmarva Land Grant Institution Cooperative Seed Grant Program of the University of Delaware, University of Maryland College Park, and University of Maryland Eastern Shore. Sea level rise and storm surge modeling was supported by the William Penn Foundation.

Acknowledgments: We would like to thank Joseph Sullivan for helpful early comments on the study design, Jim Bardsley for assistance with field investigation, and UD and UMD student research technicians Nathaly Rodriguez, Margaret Bayalis, Megan Carr, Zoe Read, Madeline Beaudry, and Bradley Simpson.

Conflicts of Interest: The authors declare no conflict of interest. The funders had no role in the design of the study; in the collection, analyses, or interpretation of data; in the writing of the manuscript, or in the decision to publish the results. 


\section{Appendix A}

Table A1. Size, population, density and Metropolitan Statistical Area of sampled municipalities.

\begin{tabular}{|c|c|c|c|c|c|c|}
\hline Municipality & State & Population & $\begin{array}{r}\text { Area } \\
\left(\mathrm{km}^{2}\right)\end{array}$ & $\begin{array}{c}\text { Population } \\
\text { Density } \\
\left(/ \mathbf{k m}^{2}\right)\end{array}$ & Metropolitan Statistical Area (MSA) & $\begin{array}{c}\text { MSA } \\
\text { Population }\end{array}$ \\
\hline Philadelphia & PA & $1,526,006$ & 370 & 4129 & $\begin{array}{l}\text { Philadelphia-Camden-Wilmington, } \\
\text { PA-NJ-DE-MD }\end{array}$ & $6,011,545$ \\
\hline Washington & DC & 601,723 & 177 & 3400 & $\begin{array}{l}\text { Washington-Arlington-Alexandria, } \\
\text { DC-VA-MD-WV }\end{array}$ & $5,695,369$ \\
\hline Norfolk & VA & 242,803 & 250 & 972 & $\begin{array}{l}\text { VA Beach-Norfolk-Newport News, } \\
\text { VA-NC }\end{array}$ & $1,685,610$ \\
\hline $\begin{array}{l}\text { Newport } \\
\text { News }\end{array}$ & VA & 180,719 & 310 & 583 & $\begin{array}{c}\text { VA Beach-Norfolk-Newport News, } \\
\text { VA-NC }\end{array}$ & $1,685,610$ \\
\hline Toms River & NJ & 88,791 & 106 & 840 & $\begin{array}{c}\text { New York-Northern NJ-Long Island, } \\
\text { NY-NJ-PA }\end{array}$ & $19,039,570$ \\
\hline Suffolk & VA & 84,585 & 1111 & 76 & $\begin{array}{l}\text { VA Beach-Norfolk-Newport News, } \\
\text { VA-NC }\end{array}$ & $1,685,610$ \\
\hline Wilmington & $\mathrm{DE}$ & 70,851 & 44 & 1615 & $\begin{array}{l}\text { Philadelphia-Camden-Wilmington, } \\
\text { PA-NJ-DE-MD }\end{array}$ & $6,011,545$ \\
\hline $\begin{array}{c}\text { New } \\
\text { Brunswick }\end{array}$ & NJ & 55,181 & 15 & 3703 & $\begin{array}{c}\text { New York-Northern NJ-Long Island, } \\
\text { NY-NJ-PA }\end{array}$ & $19,039,570$ \\
\hline Essex & MD & 39,262 & 31 & 1275 & Baltimore-Towson, MD & $2,738,814$ \\
\hline Dover & $\mathrm{DE}$ & 36,047 & 61 & 593 & Dover, DE & 166,656 \\
\hline Millville & NJ & 28,400 & 115 & 246 & Vineland-Millville-Bridgeton, NJ & 157,291 \\
\hline Bridgeton & NJ & 25,349 & 17 & 1507 & Vineland-Millville-Bridgeton, NJ & 157,291 \\
\hline Pleasantville & NJ & 20,249 & 19 & 1073 & Atlantic City-Hammonton, NJ & 273,331 \\
\hline Joppatowne & $\mathrm{MD}$ & 12,616 & 19 & 659 & Baltimore-Towson, MD & $2,738,814$ \\
\hline Neabsco & VA & 12,068 & 13 & 960 & $\begin{array}{l}\text { Washington-Arlington-Alexandria, } \\
\text { DC-VA-MD-WV }\end{array}$ & $5,695,369$ \\
\hline Ocean City & NJ & 11,701 & 30 & 391 & Ocean City, NJ & 97,616 \\
\hline Smyrna & $\mathrm{DE}$ & 10,023 & 16 & 644 & Dover, DE & 166,656 \\
\hline Edgemere & $\mathrm{MD}$ & 8669 & 53 & 163 & Baltimore-Towson, MD & $2,738,814$ \\
\hline New Castle & $\mathrm{DE}$ & 5285 & 9 & 579 & $\begin{array}{l}\text { Philadelphia-Camden-Wilmington, } \\
\text { PA-NJ-DE-MD }\end{array}$ & $6,011,545$ \\
\hline Croom & $\mathrm{MD}$ & 2631 & 92 & 29 & $\begin{array}{l}\text { Washington-Arlington-Alexandria, } \\
\text { DC-VA-MD-WV }\end{array}$ & $5,695,369$ \\
\hline
\end{tabular}

Table A2. Forb and graminoid species found across the 100 forest sites. Non-native species listed as invasive in one or more states within the study area are indicated in red.

\begin{tabular}{ccc}
\hline Scientific Name & Common Name & Growth Form \\
\hline Achillea millefolium & Yarrow & Forb \\
Ageratina altissima & White snakeroot & Forb \\
Alliaria petiolata & Garlic mustard & Forb \\
Allium vineale & Vineyard onion & Forb \\
Ambrosia artemisiifolia & Annual ragweed & Forb \\
Anagallis arvensis & Scarlet pimpernel & Forb \\
Apocynum & Dogbane & Forb \\
Apocynum cannabinum & Indian hemp & Forb \\
Arisaema triphyllum & Jack-in-the-pulpit & Forb \\
Artemisia vulgaris & Common wormwood & Forb \\
Asarum canadense & Canadian wild ginger & Forb \\
Bidens & Beggarticks & Forb \\
Boehmeria & False nettle & Forb \\
Botrychium virginianum & Rattlesnake fern & Forb \\
Chaerophyllum tainturieri & Hairy-fruit chervil & Forb \\
Circaea lutetiana & Enchanter's nightshade & Forb \\
Commelina communis & Asiatic dayflower & Forb \\
Convallaria majalis & European lily of the valley & Forb \\
Conyza canadensis & Canadian horseweed & Forb \\
Diodia teres & Rough buttonweed & Forb \\
Duchesnea indica & Mock strawberry & Forb \\
\hline
\end{tabular}


Table A2. Cont.

\begin{tabular}{|c|c|c|}
\hline Scientific Name & Common Name & Growth Form \\
\hline Eclipta prostrata & False daisy & Forb \\
\hline Erechtites hieraciifolius & American burnweed & Forb \\
\hline Erigeron annuus & Annual fleabane & Forb \\
\hline Eurybia & Aster & Forb \\
\hline Euthamia graminifolia & Flat-top goldentop & Forb \\
\hline Fabaceae sp & Legume & Forb \\
\hline Froelichia gracillis & Slender snakecotton & Forb \\
\hline Geum canadense & White avens & Forb \\
\hline Glechoma hederacea & Ground ivy & Forb \\
\hline Helenium autumnale & Common sneezeweed & Forb \\
\hline Heterotheca subaxillaris & Camphorweed & Forb \\
\hline Impatiens capensis & Spotted jewelweed & Forb \\
\hline Lespedeza cuneata & Chinese bush-clover & Forb \\
\hline Lobelia cardinalis & Cardinal flower & Forb \\
\hline Lycopodium & Clubmoss & Forb \\
\hline Lysimachia nummularia & Moneywort & Forb \\
\hline Maianthemum canadense & Mayflower & Forb \\
\hline Matteuccia struthiopteris & Ostrich fern & Forb \\
\hline Oenothera biennis & Small flowered evening primrose & Forb \\
\hline Onoclea sensibilis & Sensitive fern & Forb \\
\hline Osmorhiza longistylis & Aniseroot & Forb \\
\hline Osmunda cinnamomea & Cinnamon fern & Forb \\
\hline Oxalis corniculata & Creeping wood sorrel & Forb \\
\hline Oxalis stricta & Upright yellow wood sorrel & Forb \\
\hline Phytolacca americana & Pokeweed & Forb \\
\hline Pilea pumila & Canadian clearweed & Forb \\
\hline Plantago & Plantain & Forb \\
\hline Plantago lanceolata & English plantain & Forb \\
\hline Plantago rugelii & Black-seed plantain & Forb \\
\hline Podophyllum peltatum & May-apple & Forb \\
\hline Polygonatum & Solomon's seal & Forb \\
\hline Polygonatum biflorum & King Solomon's seal & Forb \\
\hline Polygonum cuspidatum & Japanese knotweed & Forb \\
\hline Polygonum persicaria & Spotted ladysthumb & Forb \\
\hline Polygonum virginianum & Jumpseed & Forb \\
\hline Polystichum acrostichoides & Christmas fern & Forb \\
\hline Potentilla canadensis & Dwarf cinquefoil & Forb \\
\hline Rudbeckia laciniata & Green-head coneflower & Forb \\
\hline Saururus cernuus & Lizard's tail & Forb \\
\hline Smallanthus uvedalius & Hairy leafcup & Forb \\
\hline Solanum carolinense & Carolina horse nettle & Forb \\
\hline Solidago & Goldenrod & Forb \\
\hline Symphyotrichum racemosum & Fragile-stem American-aster & Forb \\
\hline Symplocarpus foetidus & Skunk cabbage & Forb \\
\hline Taraxacum officinale & Common dandelion & Forb \\
\hline Thelypteris noveboracensis & New York fern & Forb \\
\hline Veronica arvensis & Speedwell & Forb \\
\hline Viola sororia & Common blue violet & Forb \\
\hline Yucca & Yucca & Forb \\
\hline Ammophila breviligulata & American beach grass & Graminoid \\
\hline Carex & Sedge & Graminoid \\
\hline Cyperus esculentus & Nut grass & Graminoid \\
\hline Dichanthelium clandestinum & Deer-tongue rosette grass & Graminoid \\
\hline Digitaria & Crabgrass & Graminoid \\
\hline Lolium perenne & Perennial rye grass & Graminoid \\
\hline Microstegium vimineum & Japanese stilt grass & Graminoid \\
\hline Phragmites australis & Common reed & Graminoid \\
\hline Poa pratensis & Kentucky bluegrass & Graminoid \\
\hline Poaceae & Grass & Graminoid \\
\hline
\end{tabular}


Table A2. Cont.

\begin{tabular}{ccc}
\hline Scientific Name & Common Name & Growth Form \\
\hline Ampelopsis brevipedunculata & Amur peppervine & Vine \\
Amphicarpaea bracteata & American hog-peanut & Vine \\
Calystegia sepium & Western hedge bindweed & Vine \\
Campsis radicans & Trumpet creeper & Vine \\
Celastrus orbiculatus & Asian bittersweet & Vine \\
Clematis terniflora & Sweet autumn virginsbower & Vine \\
Convolvulus & Bindweed & Vine \\
Echinocystis lobata & Wild cucumber & Vine \\
Euonymus fortunei & Winter creeper & Vine \\
Hedera helix & English ivy & Vine \\
Ipomoea purpurea & Common morning glory & Vine \\
Lonicera japonica & Japanese honeysuckle & Vine \\
Mitchella repens & Partridge-berry & Vine \\
Parthenocissus quinquefolia & Virginia creeper & Vine \\
Persicaria perfoliata & Mile-a-minute & Vine \\
Polygonum perfoliatum & Asiatic tearthumb & Vine \\
Pueraria & Kudzu & Vine \\
Sicyos angulatus & One-seed burr-cucumber & Vine \\
Smilax & Greenbrier & Vine \\
Smilax bona-nox & Fringed greenbrier & Vine \\
Smilax glauca & Sawbrier & Vine \\
Smilax rotundifolia & Horsebrier & Vine \\
Toxicodendron radicans & Eastern poison ivy & Vine \\
Vinca major & Greater periwinkle & Vine \\
Vinca minor & Common periwinkle & Vine \\
Vitis & Grape & Vine \\
Vitis aestivalis & Summer grape & Vine \\
Vitis riparia & River-bank grape & Vine \\
Vitis rotundifolia & Juscadine & Vine \\
Wisteria floribunda & Vine \\
\hline & &
\end{tabular}

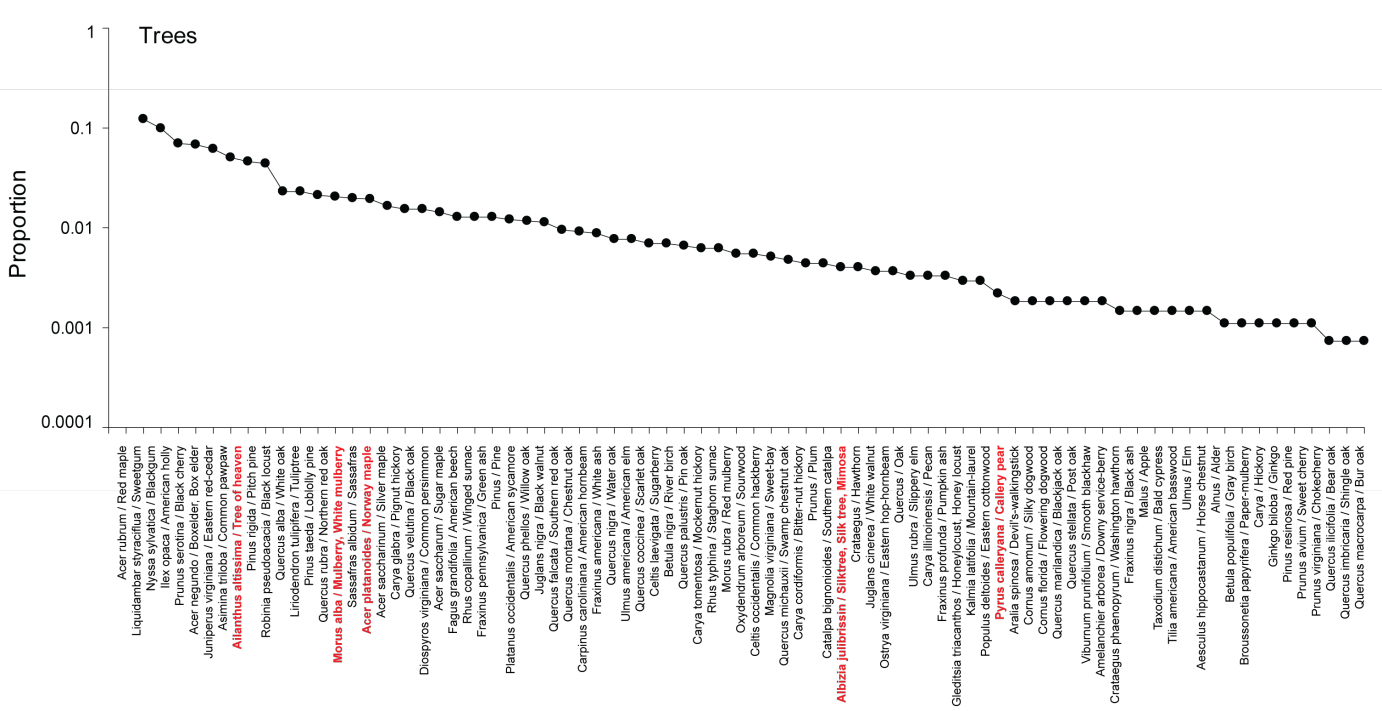

(a)

Figure A1. Cont. 


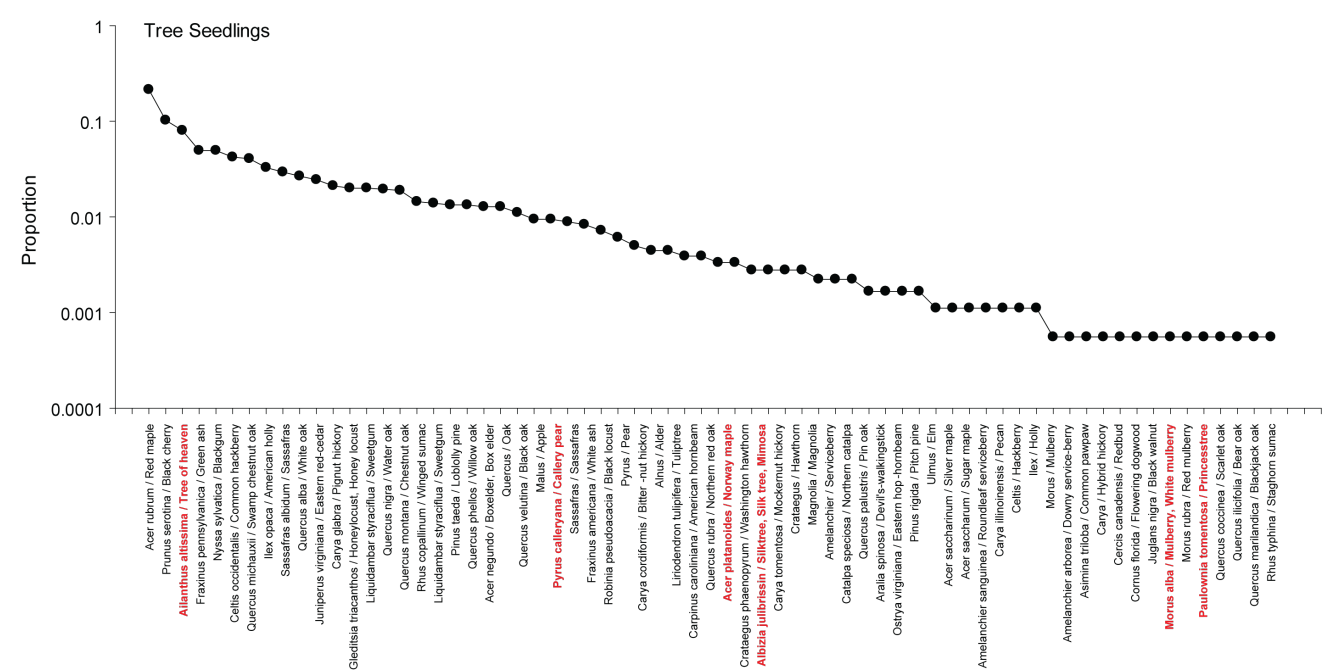

(b)

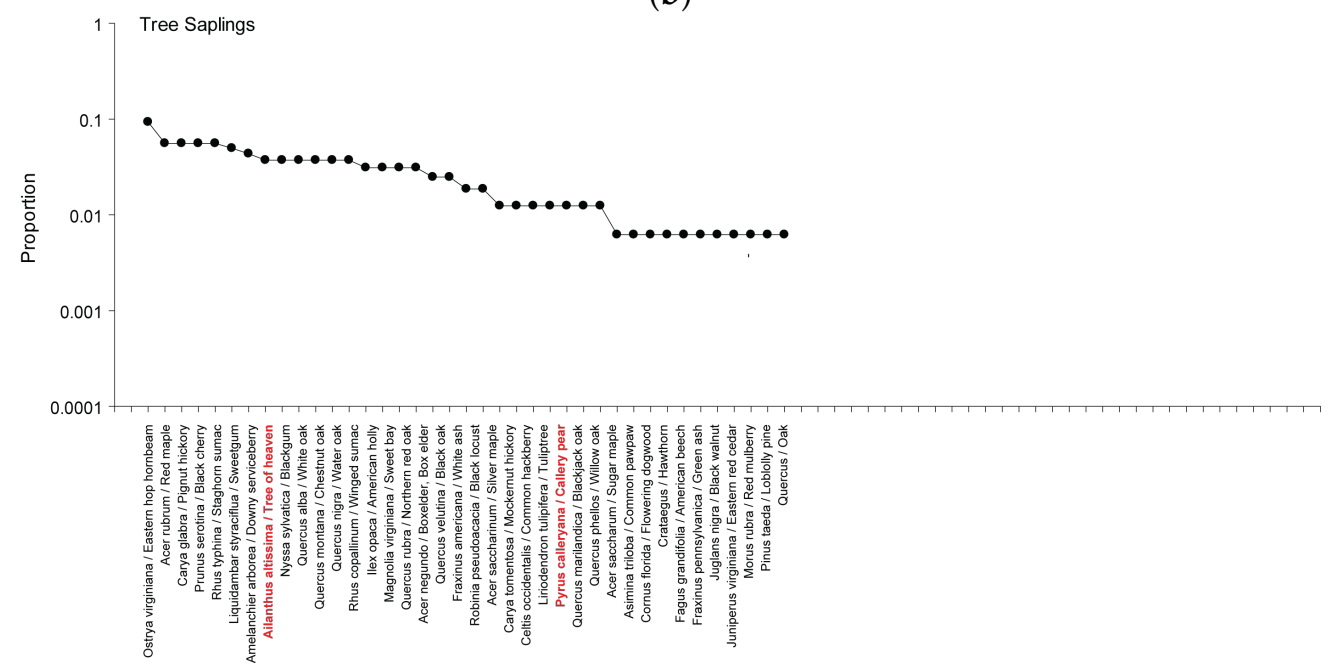

(c)

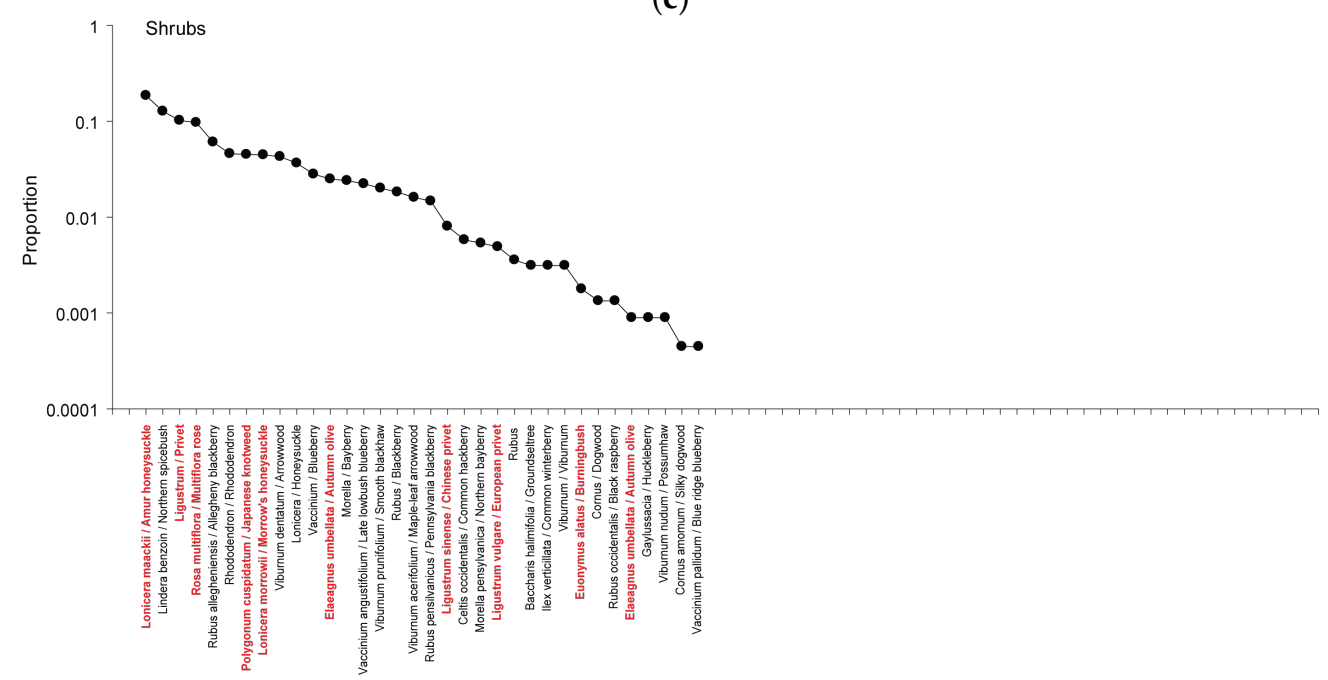

(d)

Figure A1. Rank abundance of woody species by growth form. Rank abundance of (a) canopy trees, (b) tree saplings (c) tree seedlings, and (d) shrubs found across 100 urban-adjacent riparian forest patches in the coastal Chesapeake and Delaware Bay watersheds. Non-native species listed as invasive in one or more states within the study area are indicated in red. 


\section{References}

1. Hopper, T.; Meixler, M.S. Modeling Coastal Vulnerability through Space and Time. PLoS ONE 2016, 11, e0163495. [CrossRef]

2. Menéndez, M.; Woodworth, P.L. Changes in extreme high water levels based on a quasi-global tide-gauge data set. J. Geophys. Res. Oceans 2010, 115. [CrossRef]

3. Needham, H.F.; Keim, B.D.; Sathiaraj, D. A review of tropical cyclone-generated storm surges: Global data sources, observations, and impacts. Rev. Geophys. 2015, 53, 545-591. [CrossRef]

4. $\quad$ Reed, A.J.; Mann, M.E.; Emanuel, K.A.; Lin, N.; Horton, B.P.; Kemp, A.C.; Donnelly, J.P. Increased threat of tropical cyclones and coastal flooding to New York City during the anthropogenic era. Proc. Natl. Acad. Sci. 2015, 112, 12610-12615. [CrossRef] [PubMed]

5. Grimmond, C. Urban climate in the coastal zone: Resilience to weather extremes. In Megacities and the Coast: Transformation for Resilience. A Preliminary Review of Knowledge, Practice and Future Research; Pelling, M., Ed.; LOICZ: Chennai, India, 2011.

6. Hugo, G. Future demographic change and its interactions with migration and climate change. Glob. Environ. Chang. 2011, 21, S21-S33. [CrossRef]

7. Kowarik, I. On the Role of Alien Species in Urban Flora and Vegetation. In Urban Ecology; Marzluff, J.M., Shulenberger, E., Endlicher, W., Alberti, M., Bradley, G., Ryan, C., Simon, U., ZumBrunnen, C., Eds.; Springer: New York, NY, USA, 2008; pp. 321-338, ISBN 978-0-387-73411-8.

8. Zipperer, W.C.; Guntenspergen, G.R. Vegetation composition and structure of forest patches along urban-rural gradients. In Ecology of Cities and Towns: A Comparative Approach; McDonnell, M.J., Hahs, A.K., Breuste, J.H., Eds.; Cambridge University Press: New York, NY, USA, 2009.

9. McDonnell, M.J.; Pickett, S.T.A.; Groffman, P.; Bohlen, P.; Pouyat, R.V.; Zipperer, W.C.; Parmelee, R.W.; Carreiro, M.M.; Medley, K. Ecosystem processes along an urban-to-rural gradient. Urban Ecosyst. 1997, 1, 21-36. [CrossRef]

10. Matlack, G.R. Sociological edge effects: Spatial distribution of human impact in suburban forest fragments. Environ. Manag. 1993, 17, 829-835. [CrossRef]

11. Lehvävirta, S.; Vilisics, F.; Hamberg, L.; Malmivaara-Lämsä, M.; Kotze, D.J. Fragmentation and recreational use affect tree regeneration in urban forests. Urban For. Urban Green. 2014, 13, 869-877. [CrossRef]

12. Nassauer, J.I. Messy ecosystems, orderly frames. Landsc. J. 1995, 14, 161-170. [CrossRef]

13. Nassauer, J.I.; Wang, Z.; Dayrell, E. What will the neighbors think? Cultural norms and ecological design. Landsc. Urban Plan. 2009, 92, 282-292. [CrossRef]

14. Grimm, N.B.; Sheibley, R.W.; Crenshaw, C.L.; Dahm, C.N.; Roach, W.J.; Zeglin, L.H. N retention and transformation in urban streams. J. North Am. Benthol. Soc. 2005, 24, 626-642. [CrossRef]

15. Groffman, P.M.; Boulware, N.J.; Zipperer, W.C.; Pouyat, R.V.; Band, L.E.; Colosimo, M.F. Soil Nitrogen Cycle Processes in Urban Riparian Zones. Environ. Sci. Technol. 2002, 36, 4547-4552. [CrossRef] [PubMed]

16. Hughes, R.M.; Dunham, S.; Maas-Hebner, K.G.; Yeakley, J.A.; Schreck, C.; Harte, M.; Molina, N.; Shock, C.C.; Kaczynski, V.W.; Schaeffer, J. A Review of Urban Water Body Challenges and Approaches: (1) Rehabilitation and Remediation. Fisheries 2014, 39, 18-29. [CrossRef]

17. Desantis, L.R.G.; Bhotika, S.; Williams, K.; Putz, F.E. Sea-level rise and drought interactions accelerate forest decline on the Gulf Coast of Florida, USA. Glob. Chang. Biol. 2007, 13, 2349-2360. [CrossRef]

18. Williams, K.; Ewel, K.C.; Stumpf, R.P.; Putz, F.E.; Workman, T.W. Sea-Level Rise and Coastal Forest Retreat on the West Coast of Florida, Usa. Ecology 1999, 80, 2045-2063. [CrossRef]

19. Solomon, S.; Matthews, D.; Raphael, M.; Steffen, K. Climate Stabilization Targets: Emissions, Concentrations, and Impacts over Decades to Millennia; National Academies Press: Washington, DC, USA, 2011.

20. Nicholls, R.J. Impacts of and Responses to Sea-Level Rise. In Understanding Sea-Level Rise and Variability; John Wiley \& Sons, Ltd.: Hoboken, NJ, USA, 2010; pp. 17-51, ISBN 978-1-4443-2327-6.

21. Rosenzweig, C.; Solecki, W.; Hammer, S.A.; Mehrotra, S. Cities lead the way in climate-change action. Nature 2010, 467, 909-911. [CrossRef]

22. Aronson, M.F.J.; Nilon, C.H.; Lepczyk, C.A.; Parker, T.S.; Warren, P.S.; Cilliers, S.S.; Goddard, M.A.; Hahs, A.K.; Herzog, C.; Katti, M.; et al. Hierarchical filters determine community assembly of urban species pools. Ecology 2016, 97, 2952-2963. [CrossRef] 
23. Niemiera, A.X.; Holle, B.V. Invasive Plant Species and the Ornamental Horticulture Industry. In Management of Invasive Weeds; Inderjit, Ed.; Springer: Dordrecht, The Netherlands, 2009; pp. 167-187, ISBN 978-1-4020-9202-2.

24. Reichard, S.H.; White, P. Horticulture as a Pathway of Invasive Plant Introductions in the United States Most invasive plants have been introduced for horticultural use by nurseries, botanical gardens, and individuals. BioScience 2001, 51, 103-113. [CrossRef]

25. Horvitz, C.C.; Pascarella, J.B.; McMann, S.; Freedman, A.; Hofstetter, R.H. Functional Roles of Invasive Non-Indigenous Plants in Hurricane-Affected Subtropical Hardwood Forests. Ecol. Appl. 1998, 8, 947-974. [CrossRef]

26. Kuebbing, S.E.; Souza, L.; Sanders, N.J. Effects of co-occurring non-native invasive plant species on old-field succession. For. Ecol. Manag. 2014, 324, 196-204. [CrossRef]

27. Ehrenfeld, J.G. Effects of Exotic Plant Invasions on Soil Nutrient Cycling Processes. Ecosystems 2003, 6, 503-523. [CrossRef]

28. Dassonville, N.; Vanderhoeven, S.; Gruber, W.; Meerts, P. Invasion by Fallopia japonica increases topsoil mineral nutrient concentrations. Écoscience 2007, 14, 230-240. [CrossRef]

29. Heneghan, L.; Steffen, J.; Fagen, K. Interactions of an introduced shrub and introduced earthworms in an Illinois urban woodland: Impact on leaf litter decomposition. Pedobiologia 2007, 50, 543-551. [CrossRef]

30. von der Lippe, M.; Kowarik, I. Do cities export biodiversity? Traffic as dispersal vector across urban-rural gradients. Divers. Distrib. 2008, 14, 18-25. [CrossRef]

31. Smith, I.A.; Hutyra, L.R.; Reinmann, A.B.; Marrs, J.K.; Thompson, J.R. Piecing together the fragments: Elucidating edge effects on forest carbon dynamics. Front. Ecol. Environ. 2018, 16, 213-221. [CrossRef]

32. Trammell, T.L.E.; Carreiro, M.M. Vegetation composition and structure of woody plant communities along urban interstate corridors in Louisville, KY, U.S.A. Urban Ecosyst. 2011, 14, 501-524. [CrossRef]

33. Matthews, E.R.; Schmit, J.P.; Campbell, J.P. Climbing vines and forest edges affect tree growth and mortality in temperate forests of the U.S. Mid-Atlantic States. For. Ecol. Manag. 2016, 374, 166-173. [CrossRef]

34. Aronson, M.F.J.; Handel, S.N. Deer and Invasive Plant Species Suppress Forest Herbaceous Communities and Canopy Tree Regeneration. Nat. Areas J. 2011, 31, 400-407. [CrossRef]

35. Mackun, P.; Wilson, S.; Fischetti, T.; Goworowska, J. Population Distribution and Change: 2000 to 2010; 2010 Census Briefs; Census Bureau, U.S, Department of Commerce, Economics and Statistics Administration: Suitland, MD, USA, 2011; p. 12. Available online: http://www.census.gov/prod/cen2010/briefs/c2010br-01.pdf (accessed on 7 February 2020).

36. Nowak, D.; Walton, J. Projected Urban Growth (2000-2050) and Its Estimated Impact on the US Forest Resource. J. For. 2005, 103, 383-772.

37. Jantz, P.; Goetz, S.; Jantz, C. Urbanization and the Loss of Resource Lands in the Chesapeake Bay Watershed. Environ. Manag. 2005, 36, 808-825. [CrossRef]

38. Titus, J.G.; Hudgens, D.E.; Hershner, C.; Kassakian, J.M.; Penumalli, P.R.; Berman, M.; Nuckols, W.H. Virginia; The Likelihood of Shore Protection along the Atlantic Coast of the United States; Mid-Atlantic: Washington, DC, USA, 2010.

39. U.S. Global Change Research Program. Global Climate Change Impacts in the United States; Cambridge University Press: Cambridge, UK, 2009; ISBN 978-0-521-14407-0.

40. ESRI. ArcGIS Desktop; Environmental Systems Research Institute: Redlands, CA, USA, 2017.

41. NRCS. Watershed Boundary Dataset; United States Department of Agriculture-Natural Resources Conservation Service (USDA-NRCS), the United States Geological Survey (USGS), and United States Environmental Protection Agency (EPA): Washington, DC, USA, 2019.

42. USGS. NLCD 2011 Land Cover (2011 Edition, amended 2014)_National Geospatial Data Asset (NGDA) Land Use Land Cover; U.S. Geological Survey: Sioux Falls, SD, USA, 2014.

43. Avins, M. Baltimore's Forest Patches: Emerald Assets for Ecosystem Services; Baltimore Greenspace: Baltimore, MD, USA, 2013; p. 34.

44. Jelesnianski, C.P.; Chen, J.; Shaffer, W.A. SLOSH: Sea, Lake, and Overland Surges from Hurricanes; National Oceanic and Atmospheric Administration, U.S. Department of Commerce: Washington, DC, USA, 1992; p. 71.

45. NOAA Sea, Lake, and Overland Surges from Hurricanes (SLOSH). Available online: https://www.nhc.noaa. gov/surge/slosh.php (accessed on 15 October 2016). 
46. Barth, J.; Drzyzga, S.A. Modeling the extent of future storm surge inundation under two sea level rise scenarios. Poster Presented at the US International Association for Landscape Ecology 2017 Annual Meeting, Baltimore, MD, USA, 9-13 April 2017.

47. NOAA National Oceanic and Atmospheric Administration Coastal Services Center Coastal Inundation Digital Elevation Model. Available online: https://coast.noaa.gov/slrdata/ (accessed on 15 October 2016).

48. USGS National Elevation Dataset (NED). Available online: https://www.usgs.gov/core-science-systems/ngp/ 3dep/about-3dep-products-services (accessed on 15 October 2016).

49. USGS National Hydrography Dataset. Available online: https://www.usgs.gov/core-science-systems/ngp/ national-hydrography/national-hydrography-dataset (accessed on 15 October 2016).

50. Lautar, K.; Yesilonis, I.; Schumaker, N.; Baker, M. Schumaker Vine Invasion Index. In Baltimore Greenspace Forest Surveying Project Revised Field Protocol; Baltimore Greenspace, Ed.; Baltimore Greenspace: Baltimore, MD, USA, 2017.

51. USDA, N. The PLANTS Database; National Plant Data Team: Greensboro, NC, USA, 2019.

52. PA-DCNR Invasive Plant Fact Sheets. Available online: https://www.dcnr.pa.gov:443/Conservation/ WildPlants/InvasivePlants/InvasivePlantFactSheets/Pages/default.aspx (accessed on 22 October 2019).

53. MISC Maryland Invasive Species Council Species of Concern. Available online: http://mdinvasives.org/ species-of-concern/ (accessed on 22 October 2019).

54. McAvoy, W.A. Non-Native Invasive Plants of Delaware; Species Conservation and Research Program, Delaware Division of Fish and Wildlife, Delaware Department of Natural Resources and Environmental Control: Smyrna, Turkey, 2018; p. 7.

55. Heffernan, K.; Engle, E.; Richardson, C. Virginia Invasive Plants Species List; Natural Heritage Technical Document; Virginia Department of Conservation and Recreation, Division of Natural Heritage: Richmond, BC, Canada, 2014.

56. State of New Jersey Department of Environmental Protection; NJ Fortest Service. Invasive Species. Available online: https://www.state.nj.us/dep/parksandforests/forest/invasive_species.html (accessed on 22 October 2019).

57. Gleason, H.A.; Cronquist, A. Manual of Vascular Plants of Northeastern United States and Adjacent Canada; 2 Sub.; New York Botanical Garden: New York, NY, USA, 1991; ISBN 0-89327-365-1.

58. Holmgren, N.H.; Holmgren, P.K.; Gleason, H.A. Illustrated companion to Gleason and Cronquist's manual: Illustrations of the vascular plants of northeastern United States and adjacent Canada; New York Botanical Garden: New York, NY, USA, 1998.

59. Weakley, A.S.; Ludwig, J.C.; Townsend, J.F. Flora of Virginia, 1st ed.; Botanical Research Inst of Texas: Fort Worth, TX, USA, 2012; ISBN 978-1-889878-38-6.

60. Rhoads, A.F.; Block, T.A. The Plants of Pennsylvania: An Illustrated Manual, 2nd ed.; University of Pennsylvania Press: Philadelphia, PA, USA, 2007; ISBN 978-0-8122-4003-0.

61. Mid-Atlantic Wetlands Workgroup. MidTRAM: Mid-Atlantic Tidal Wetland Rapid Assessment Method, Version 3.0; Delaware Department of Natural Resources and Environmental Control, Division of Water Resources; Maryland Department of Natural Resources, Riparian and Wetland Restoration Services; Virginia Institute of Marine Science, Center for Coastal Resources Management; Mid-Atlantic Wetlands Workgroup: Gloucester, VA, USA, 2010; p. 55.

62. Bourdaghs, M. Development of a Rapid Floristic Quality Assessment 2012. Available online: https://www.pca.state.mn.us/sites/default/files/wq-bwm2-02a.pdf (accessed on 7 February 2020).

63. Harrison, J.W. The Natural Communities of Maryland 2016 Natural Community Classification Framework 2016. Available online: https://dnr.maryland.gov/wildlife/Documents/Natural_Communities\%20_Maryland_ 2016_Framework.pdf (accessed on 7 February 2020).

64. PA DEP. Pennsylvania Riverine Condition Level 2 Rapid Assessment Protocol, Version 1.0; Pennsylvania Department of Environmental Protection, Bureau of Waterways Engineering and Wetlands, Division of Wetlands, Encroachments and Training: Harrisburg, PA, USA, 2016; p. 33.

65. Pregitzer, C.C.; Charlop-Powers, S.; Bibbo, S.; Forgione, H.M.; Gunther, B.; Hallett, R.A.; Bradford, M.A. A city-scale assessment reveals that native forest types and overstory species dominate New York City forests. Ecol. Appl. 2019, 29, e01819. [CrossRef] [PubMed]

66. Natural Resources Group. UFEP Protocol for Plot Establishment; New York City Department of Parks and Recreation: New York, NY, USA, 1992. 
67. Amrein, D.; Rusterholz, H.-P.; Baur, B.; Fraser, L. Disturbance of suburban Fagus forests by recreational activities: Effects on soil characteristics, above-ground vegetation and seed bank. Appl. Veg. Sci. 2005, 8, 175-182.

68. Grimm, N.B.; Pickett, S.T.A.; Hale, R.L.; Cadenasso, M.L. Does the ecological concept of disturbance have utility in urban social-ecological-technological systems? Ecosyst. Health Sustain. 2017, 3. [CrossRef]

69. Johnson, L.R.; Handel, S.N. Restoration treatments in urban park forests drive long-term changes in vegetation trajectories. Ecol. Appl. 2016, 26, 940-956. [CrossRef]

70. Hobbs, R.J. Disturbance, diversity, and invasion: Implications for conservation. Conserv. Biol. 1992, 6, 324-337. [CrossRef]

71. The Ecology of Natural Disturbance and Patch Dynamics; Pickett, S.T.A.; White, P.S. (Eds.) Academic Press: San Diego, CA, USA, 1985; ISBN 978-0-12-554521-1.

72. Beauchamp, V.B.; Ghuznavi, N.; Koontz, S.M.; Roberts, R.P. Edges, exotics and deer: The seed bank of a suburban secondary successional temperate deciduous forest. Appl. Veg. Sci. 2013, 16, 571-584. [CrossRef]

73. Russell, M.B.; Woodall, C.W.; Potter, K.M.; Walters, B.F.; Domke, G.M.; Oswalt, C.M. Interactions between white-tailed deer density and the composition of forest understories in the northern United States. For. Ecol. Manag. 2017, 384, 26-33. [CrossRef]

74. Robertson, D.J. Trees, deer and non-native vines: Two decades of northern piedmont forest restoration. Ecol. Restor. 2012, 30, 59-70. [CrossRef]

75. Ward, J.S.; Williams, S.C.; Linske, M.A. Independent Effects of Invasive Shrubs and Deer Herbivory on Plant Community Dynamics. Forests 2017, 8, 2. [CrossRef]

76. Walsh, C.J.; Roy, A.H.; Feminella, J.W.; Cottingham, P.D.; Groffman, P.M.; Morgan, R.P.I. The urban stream syndrome: Current knowledge and the search for a cure. J. North Am. Benthol. Soc. 2005, 24, 706-723. [CrossRef]

77. Botequilha Leitão, A.; Miller, J.; Ahern, J.; McGarigal, K. Measuring Landscapes: A Professional Planner's Manual; Island Press: Washington, DC, USA, 2006.

78. McCabe, T.; McCabe, R. Recounting whitetails past. In The Science of Overabundance: Deer Ecology and Population Managment; McShea, W., Underwood, H., Rappole, J., Eds.; Smithsonian Institution: Washington, DC, USA, 1997; pp. 11-26.

79. Magnuson, J.J. Long-Term Ecological Research and the Invisible Present. BioScience 1990, 40, 495-501. [CrossRef]

80. Turner, M.G.; Gardner, R.H. (Eds.) Landscape Ecology in Theory and Practice: Pattern and Process; Springer: New York, NY, USA, 2015; ISBN 978-1-4939-2794-4. 